NBER WORKING PAPER SERIES

\title{
THE MEDIUM-TERM IMPACTS OF HIGH-ACHIEVING CHARTER SCHOOLS ON NON-TEST SCORE OUTCOMES
}

\author{
Will Dobbie \\ Roland G. Fryer, Jr \\ Working Paper 19581 \\ http://www.nber.org/papers/w19581 \\ NATIONAL BUREAU OF ECONOMIC RESEARCH \\ 1050 Massachusetts Avenue \\ Cambridge, MA 02138 \\ October 2013
}

Special thanks to Geoffrey Canada and the Harlem Children's Zone staff, Darryl Cobb, Kevin Hall, and Stephen Hinson from the Charter School Growth Fund, Kyle Cole and the Noble Charter Network, DSST Public Schools, and Summit Public Schools for their support and leadership during this project. We are grateful to David Deming and Lawrence Katz for helpful comments and suggestions. Ainara Arcelus, Everton Blair, Sara D'Alessandro, Matt Davis, Philipp Grimm, Blake Heller, Cody Melcher, Julene Paul, Lisa Phillips, Sameer Sampat, Allison Sikora, Carmen Tracy, and Rucha Vankudre provided exceptional research assistance and project management support. Robin Jacob, Karin Schneider, and the staff at the Institute for Social Research at the University of Michigan provided excellent data managementlland survey administration assistance. Financial support from the Broad Foundation and the Ford Foundationlis gratefully acknowledged. Correspondence can be addressed to the authors by[e-mail at wdobbie@ princeton.edu[[Dobbie] or rfryer@fas.harvard.edu [Fryer]. The usual caveat applies. The views expressed hereinlare those of the authors and do not necessarily reflect the views of the National Bureau of Economic $\llbracket$ Research.

NBER working papers are circulated for discussion and comment purposes. They have not been peerreviewed or been subject to the review by the NBER Board of Directors that accompanies official NBER publications.

(C) 2013 by Will Dobbie and Roland G. Fryer, Jr. All rights reserved. Short sections of text, not to exceed two paragraphs, may be quoted without explicit permission provided that full credit, including @ notice, is given to the source. 
The Medium-Term Impacts of High-Achieving Charter Schools on Non-Test Score Outcomes Will Dobbie and Roland G. Fryer, Jr

NBER Working Paper No. 19581

October 2013

JEL No. J01,J15

\begin{abstract}
$\underline{\text { ABSTRACT }}$
High-performing charter schools can significantly increase the test scores of poor urban students. It is unclear whether these test score gains translate into improved outcomes later in life. We estimate the effects of high-performing charter schools on human capital, risky behaviors, and health outcomes using survey data from the Promise Academy in the Harlem Children's Zone. Six years after the random admissions lottery, youth offered admission to the Promise Academy middle school score 0.283 standard deviations higher on a nationally-normed math achievement test and are 14.1 percentage points more likely to enroll in college. Admitted females are 12.1 percentage points less likely to be pregnant in their teens, and males are 4.3 percentage points less likely to be incarcerated. We find little impact of the Promise Academy on self-reported health. We conclude with speculative evidence that highperforming schools may be sufficient to significantly improve human capital and reduce certain risky behaviors among the poor.
\end{abstract}

\author{
Will Dobbie \\ Industrial Relations Section \\ Princeton University \\ Firestone Library \\ Princeton, NJ 08544-2098 \\ wdobbie@princeton.edu \\ Roland G. Fryer, Jr \\ Department of Economics \\ Harvard University \\ Littauer Center 208 \\ Cambridge, MA 02138 \\ and NBER \\ rfryer@fas.harvard.edu
}

An online appendix is available at:

http://www.nber.org/data-appendix/w19581 
"Education is the best provision for old age." Aristotle

\section{Introduction}

The typical charter school is no more effective at increasing test scores than the typical traditional public school (Gleason et al. 2010). Yet, an emerging body of research using admissions lotteries suggests that high-performing charter schools can significantly increase the achievement of poor urban students. Students attending over-subscribed Boston-area charter schools score approximately 0.4 standard deviations (hereafter $\sigma$ ) higher per year in math and $0.2 \sigma$ higher per year in reading (Abdulkadiroglu et al. 2011). Promise Academy students in the Harlem Children's Zone (HCZ) score $0.229 \sigma$ higher per year in math and $0.047 \sigma$ higher per year in reading (Dobbie and Fryer 2011a). The Knowledge is Power Program (KIPP) schools - America's largest network of charter schools - and the SEED urban boarding school in Washington D.C. experience similar test score gains (Angrist et al. 2010, Tuttle et al. 2010, Curto and Fryer forthcoming).

An important open question is whether these increases in student achievement translate into comparable gains on medium-term outcomes such as high school graduation, college enrollment, drug-use, teen pregnancy, or incarceration. Charter advocates argue that high-performing charter schools are effective at implementing educational "best-practices" - frequent teacher feedback, datadriven instruction, an extended school day and year, and a relentless focus on achievement - which develop basic skills that lead to both gains on short-run state test scores and longer-term non-tested measures (Carter 2000, Thernstrom and Thernstrom 2004, Whitman 2008). ${ }^{1}$ Conversely, critics argue that high-performing charter schools increase test scores through intense test prep (Haladyna, Nolen, and Hass 1991, Haladyna 2006, Jacob 2005), a paternalistic environment (Whitman 2008), strategic resource allocation (Jacob 2005), or blatant cheating (Jacob and Levitt 2003), without instilling long-term or general knowledge in their students.

In this paper, we use data from the Promise Academy in the HCZ to provide a "proof of concept" that the best practices used by high-performing charter schools can impact mediumterm outcomes (in section 5.1 we also analyze data from four additional high performing charter schools). Like many other high-performing charters, the Promise Academy largely adheres to

\footnotetext{
${ }^{1}$ There is also evidence that students assigned to high test score value-add teachers are more likely to attend college, earn higher salaries as adults, and are less likely to become pregnant as teenagers (Chetty, Friedman, and Rockoff 2011). Additionally, attending a high-quality public school can reduce crime and increase college enrollment even when there is little impact on state test scores (Cullen, Jacob, and Levitt 2006, Deming 2011, Deming et al. 2011), perhaps due to the development of non-tested forms of intelligence or changes in social networks (Heckman and Rubenstein 2001, Heckman et al. 2006, Segal 2008, Whitman 2008, Chetty et al. 2011).
} 
the five tenets of effective charter schools identified by Dobbie and Fryer (2011b). The school has an extended school day and year, emphasizes the recruitment and retention of high-quality teachers, uses extensive data-driven monitoring to track student progress and assign students to small group-tutoring sessions based on these data, and makes a concerted effort to change the culture of achievement (Dobbie and Fryer 2011b). Appendix Table 1 provides evidence that suggests the Promise Academy charter school is emblematic of other successful charter schools, not an outlier.

Our identification strategy exploits the fact that the Promise Academy is required to select students by lottery when the number of applicants exceeds the number of available slots for admission. The treatment group is composed of youth who are lottery winners and the control group consists of youth who are lottery losers. This empirical strategy allows us to provide a set of causal estimates of the effects of the Promise Academy.

Outcomes for our analysis come from survey data collected from youth entered in the 2005 and 2006 Promise Academy sixth grade admissions lotteries. The survey included questions about educational achievement and attainment, risky behaviors, and health outcomes. We also administered the Woodcock-Johnson math and reading tests as an alternative measure of cognitive ability, and included questions on a number of potential mechanisms such as non-cognitive skills, social networks, risk aversion, and discount rates. We surveyed 407 out of 570 lottery entrants, a high response rate for survey studies on low-income urban youth (Cullen, Jacob, and Levitt 2006, Kling, Liebman, and Katz 2007, Rodriguez-Planas 2012). We augment this survey data with administrative data on high school course-taking from the New York City Department of Education (NYCDOE) and college enrollment data from the National Student Clearinghouse (NSC).

We find that the Promise Academy increases a wide range of human capital measures. Six years after the admissions lottery, lottery winners outscore lottery losers by $0.283 \sigma$ higher on the no-stakes Woodcock-Johnson math exam, and by $0.119 \sigma$ on the Woodcock-Johnson reading exam. On New York City's high school Regents exams, designed to measure mastery in core subjects, lottery winners pass approximately one additional exam, score $0.270 \sigma$ higher on exams taken by the majority of the sample, and are more than twice as likely to take and pass more advanced exams such as chemistry and geometry. Lottery winners are also 14.1 percentage points more likely to enroll in college compared to lottery losers, and 21.3 percentage points more likely to enroll in a four-year college, a 102 percent increase from the control mean. Lottery winners are also 7.2 percentage points less likely to enroll in a two-year college, likely due to the fact that these youth enroll in a four-year college instead. Combining our five primary human capital variables into a 
single index measure, we find that lottery winners increase their human capital by $0.277 \sigma$ compared to lottery losers.

The Promise Academy's effect on risky behaviors is mixed and we find very little evidence of impacts on self-reported health. Female lottery winners are 12.1 percentage points less likely to report being pregnant during their teenage years, a 71 percent drop from the control mean of 17 percent among lottery losers. Male lottery winners are 4.3 percentage points less likely to be incarcerated, essentially a 100 percent drop. Students who win the lottery to attend the Promise Academy report similar drug and alcohol use and criminal behavior as students who lose the lottery. An index measure of risky behavior that combines all four variables is positive and marginally significant $(p-v a l u e=0.06)$. Finally, there is little impact of the Promise Academy on asthma, obesity, or mental health, though lottery winners are more likely to report eating nutritious foods.

We complement our main analysis with two robustness checks. First, we consider the extent to which differential sample attrition threatens our estimates by calculating Lee (2009) bounds and imputing outcomes for youth who did not respond to the survey. Lottery winners were 11.8 percentage points more likely to respond to our survey. If lottery losers who did not respond to the survey differ in some important way, this could invalidate our empirical design by creating unobserved differences between the treatment and control groups. Second, we account for multiplehypothesis testing by calculating p-values with an algorithm that accounts for the Familywise Error Rate (Westfall and Young 1993, Kling, Liebman and Katz 2007, Anderson 2008). The most conservative bounding procedures reduce some individual effects to statistical insignificance, but our main findings are not significantly altered by these robustness checks.

We conclude with a more speculative discussion on the potential mechanisms driving our results. First, we investigate the empirical importance of the HCZ neighborhood programs and the Promise Academy school policies by separately estimating the effects on youth who are more or less likely to receive neighborhood benefits based on their home address. Consistent with Dobbie and Fryer (2011a), we find little evidence that the neighborhood programs drive our results. To provide additional evidence on this issue, we also collected admissions lottery data and college enrollment data from four additional high-performing charter high schools. In this separate sample of schools, lottery winners are 4.9 percentage points more likely to enroll in college compared to lottery losers, 6.3 percentage points more likely to attend a four-year school, and 6.3 percentage points more likely to attend a selective four-year school. Second, we consider the extent to which changes in 
test scores might explain the impact of the Promise Academy on non-test score outcomes. Using the cross-sectional relationship between test scores and non-test score outcomes reported by Chetty, Friedman, and Rockoff (2011), we find that only a small portion of our estimated effects can be explained by the test score change. Third, we estimate the impact of the Promise Academy on a number of other possible mechanisms. We find little impact on non-cognitive skills, social networks, or discount rates, though lottery winners are more averse to risk than lottery losers.

Our analysis has three important caveats. First, our primary source of data is from only one New York City charter school, which could differ from other high-performing schools in important ways that limit our ability to generalize the results. As discussed earlier, the inputs and impacts of the Promise Academy are similar to other high-performing charter schools, data from four other high-performing charter schools provide similar results, and turn-around efforts that use congruent practices have yielded similar results on state test scores (Angrist et al. 2010, Tuttle et al. 2010, Abdulkadiroglu et al. 2011, Dobbie and Fryer 2011a, Fryer 2011b). We chose to obtain a higher response rate on a detailed face-to-face survey with lottery entrants from one school, as opposed to a lower rate with lottery entrants from multiple schools using online or other methods, in order to maximize the internal validity of our study. The cost of this face-to-face approach - roughly $\$ 2,150$ per student, or $\$ 895,000$ for the entire sample - necessitated the focus on a single school. ${ }^{2}$

Second, the survey respondents may not have truthfully answered our questions. In particular, it is plausible that Promise Academy students were directly or indirectly pressured to overstate the impact of the school. Arguing against this, results using administrative outcomes are even larger than the survey results, suggesting this issue does not significantly impact our findings.

Third, our analysis is necessarily limited to various medium-term outcomes. Longer-term outcomes, such as college graduation, earnings, and mortality, are not a part of our analysis due to the age of the lottery entrants.

The remainder of the paper is structured as follows. Section 2 provides a brief overview of the Harlem Children's Zone. Section 3 describes the data collected for this paper and our lottery-based research design. Section 4 estimates the impact of the Promise Academy on human capital, risky behaviors, and health. Section 5 discusses potential mechanisms. Section 6 concludes. There are six Web Appendices. Web Appendix A presents additional analyses to supplement the results in

\footnotetext{
${ }^{2}$ Interviewing a random subsample of lottery entrants from multiple schools proved to be infeasible, as there are not enough charter schools with a large enough alumni sample and binding admissions lotteries for a study with multiple high-performing schools in a single city. The additional cost of interviewing subjects in multiple cities would have forced a much smaller survey population.
} 
the text. Web Appendix B is a data appendix that details our sample and variable construction. Web Appendix $\mathrm{C}$ details the tracking and outreach efforts used to contact lottery entrants. Web Appendix D includes the full survey instrument. Web Appendix E details the algorithm used to calculate p-values corrected for multiple hypothesis-testing. Finally, Web Appendix F describes the data for our sample of high-performing charter high schools.

\section{Harlem Children's Zone}

The Harlem Children's Zone consists of over 20 neighborhood and school programs meant to address the myriad problems that children from low income families face - housing, schools, crime, asthma, and so forth - through a "conveyor belt" of services from birth to college. The approach is based on the assumption that one must improve both communities and schools to have a long-term impact on disadvantaged youth. Starting with a 24-block area in central Harlem, the Zone expanded to a 64-block area in 2004 and a 97-block area in 2007.

\section{Neighborhood Programs}

The HCZ neighborhood programs serve as broad investments in community development. These programs include early childhood programs, K-12 tutoring, after-school programs, a college success office, family programs, health programs, a foster-care prevention program, a tax assistance program, and so on. Consistent with Wilson's (1987) theory of non-linear neighborhood effects and cycles of poverty, HCZ's vision is to create a "tipping point" in the neighborhood so that children are surrounded by an enriching environment of college-oriented peers and supportive adults. HCZ neighborhood programs are available to anyone living near $\mathrm{HCZ}$ and serve more than 8,000 youth and 5,000 adults each year.

\section{School Programs}

The Promise Academy largely adheres to the five correlates of effective schools identified by Dobbie and Fryer (2011b). The Promise Academy has an extended school day and year with coordinated after-school tutoring and additional classes on Saturdays for children who need remediation in mathematics and English Language Arts skills. Promise Academy middle schoolers spent 1,785 hours in school during the 2010-11 school-year, 46.1 percent more time than the typical New York

City public school student and 11.8 percent more than the typical student in a high-performing New York City charter school (Dobbie and Fryer 2011b). The Promise Academy also emphasizes 
the recruitment and retention of high-quality teachers and uses measures of test score value-added to incentivize and evaluate current teachers. In the search for high-achieving teachers, the Promise Academy had high teacher turnover during the first three years of operation, with 48 percent of teachers not returning for the 2005-2006 school year, 32 percent leaving before 2006-2007, and 14 percent leaving before 2007-2008. The Promise Academy also uses extensive data-driven monitoring to track student progress and differentiate instruction, with students who have not met the required benchmarks receiving small-group tutoring. Like other "No Excuses" charters, the Promise Academy also makes a concerted effort to change the culture of achievement, stressing the importance of hard work in achieving success. It is assumed that every student will enroll in college, with the goal of establishing college attendance as the default option. ${ }^{3}$

\section{Data and Research Design}

\subsection{Data and Summary Statistics}

We merge information from lottery files at the Harlem Children's Zone, administrative records on student demographics and outcomes from the New York City Department of Education (NYCDOE), information on college enrollment from the National Student Clearinghouse (NSC), and survey data collected from Promise Academy lottery participants for the purposes of this study.

\section{Survey Data}

In order to investigate the impact of the Promise Academy on various medium-term outcomes, we conducted in-person interviews with youth who entered the 2005 and 2006 sixth grade admissions lotteries. Students entered in the 2005 sixth grade lottery were finishing or had just finished 12th grade at the time of our survey, while students entered in the 2006 sixth grade lottery were finishing or had just finished 11th grade. Web Appendix B contains additional information on the coding of variables. Web Appendix C describes our tracking and survey administration, and Web Appendix D contains the full survey instrument and protocols used to administer the survey. This section summarizes the most relevant information from our Web Appendices.

\footnotetext{
${ }^{3}$ There are at least two potentially important differences between the Promise Academy and the typical highperforming New York charter school. First, the Promise Academy does not require parents or students to sign a behavioral contract, resulting in students that are more similar to the surrounding neighborhood than other charter schools. HCZ argues that only the most motivated and trusting parents are willing to sign even a non-binding contract. Second, Promise Academy students are exposed to a wide range of wrap-around services that are not available at most charter schools. The schools provide free medical and dental services, student incentives for achievement, nutritious cafeteria meals, parental engagement and supports (e.g. bus fare, meals), and so on.
} 
From January 2012 through July 2012, we attempted to contact 570 Promise Academy lottery entrants using letters, phone calls, and home visits. ${ }^{4}$ Using information from NYCDOE administrative data, internet searches of current addresses, and publicly available address records, we were able to successfully contact 501 of these lottery entrants. Contacted youth were offered a financial incentive between $\$ 40$ and $\$ 200$ to participate in the study, with the amount increasing as the survey period progressed. Parents were also offered an additional cash incentive to review the consent form. Of the 501 lottery entrants we contacted, 407 agreed to participate in the study, 61 refused to participate in the study, and 33 were unable to participate due to distance, language barriers, health, incarceration, or another obstacle. We obtained a final response rate of 79.4 percent for lottery winners and 67.6 percent for lottery losers. Section 3.2 examines the differences between lottery winners and lottery losers who respond to our survey, finding no evidence of differential selection into our sample along observable characteristics or administrative outcomes.

The questionnaire, based largely on the comprehensive survey used to evaluate the Moving to Opportunity experiment (Kling, Liebman, and Katz 2007), took approximately 110 minutes to complete. The survey was designed to investigate three main outcomes: (1) human capital, (2) risky behaviors, and (3) health. We also asked about non-cognitive skills, peer networks, and economic preferences in order to assess potential underlying mechanisms.

Human capital is measured through the Woodcock-Johnson Broad Math and Reading tests, which is meant to augment the human capital measures available in the NYCDOE and NSC datasets. ${ }^{5}$ The Woodcock-Johnson exams are designed to test general knowledge rather than the subject-specific skills emphasized on New York State tests. The assessments are designed to be appropriate for all grades and ability levels and to have a high degree of internal reliability. ${ }^{6}$ The Woodcock-Johnson Broad Math score is composed of Applied Problems, Calculation, and Math

\footnotetext{
${ }^{4}$ There were 599 unique entrants in the 2005 and 2006 Promise Academy admissions lotteries. We randomly selected 30 lottery losers to test and calibrate the survey instrument, leaving 189 lottery winners and 381 lottery losers in the potential survey sample after a duplicate row was discovered in the pretest sample. Results are identical including the pre-test respondents.

${ }^{5}$ The Woodcock-Johnson Brief Battery that we use in our survey is an updated version of the Woodcock-Johnson Revised Battery administered as a part of the MTO evaluation. Accordingly, there is not perfect alignment between the sub-tests. We followed the advice of Woodcock-Johnson staff and administered the four sub-tests included in the MTO follow-up - Letter-Word Identification, Passage Comprehension, Applied Problems, and Calculation - in addition to the Math Fluency and Reading Fluency sections. Following Kling, Liebman, and Katz 2007, we omit the Writing sections to reduce the length of the survey. Treatment effects for each individual sub-test can be found in Web Appendix Table 3.

${ }^{6}$ Sanbonmatsu et al. (2006) analyze test results in the Panel Study of Income Dynamics Child Development Supplement and find that the internal reliability of the test is strong for a population similar to ours, with scores for eight to seventeen year-old black students showing a correlation between 0.5 and 0.6 with the same test taken five years earlier. In our sample, the correlation between students' Woodcock-Johnson scores and their eighth grade state test scores is approximately 0.6 in both math and reading.
} 
Fluency subscores. The Applied Problems section consists of word problems read aloud to youth. The Calculation section tests computation skills ranging from arithmetic to Calculus. The Math Fluency section requires youth to answer as many simple questions as possible in three minutes. The Broad Reading score consists of Letter-Word Identification, Passage Comprehension, and Reading Fluency subscores. The Letter-Word Identification section tests pronunciation of increasingly difficult words. The Passage Comprehension questions require youth to identify a word or phrase that completes a sample sentence. The Reading Fluency section, like the Math section, requires youth to answer as many simple questions as possible in three minutes. Web Appendix B contains additional details on the Woodcock-Johnson and the administration of the tests.

Risky behaviors are measured through a series of questions on pregnancy, controlled substance use, and crime. For pregnancy, we ask female youth if they have ever been pregnant, even if no child was born. In our sample, 14.6 percent of females have been pregnant at some point. We measure criminal behavior using an indicator for being in jail or prison when we contacted the lottery entrant. ${ }^{7}$ We also constructed an index based on youth' self-reported criminal behaviors, such as theft, destruction of property, fighting, or carrying a gun. The reported incidence of these behaviors is relatively low. Twenty-two percent of control youth report having ever been in a serious fight, and 14.1 percent report having stolen an item worth less than $\$ 50$. Rates of all other criminal behaviors we measure are less than ten percent. To measure drug and alcohol use, we construct a summary index based on whether a youth reports that she has consumed alcohol in the last 30 days, smoked marijuana in the last 30 days, or used hard drugs within the past year.

We measure mental health using the K6 anxiety scale used in Kling, Liebman, and Katz (2007), standardized to have a mean of zero and standard deviation of one in the control group. Physical health is measured using an index based on indicators for self-reported poor health, having had an asthma attack in the past year, having a Body Mass Index (BMI) above the 95th percentile for the respondent's age and gender, and having reported chronic health problems. To investigate health risk factors, we ask about the number of times in the past week the youth has consumed foods such as fruits and vegetables, soft drinks, savory snacks, and fast food. We use these responses to create a nutrition index, reversing the sign on the unhealthy food variables. We also construct a health behavior index from questions about having a physical examination in the past year, the frequency

\footnotetext{
${ }^{7}$ Criminal records are available for offenders over the age of 18. As much of our sample is under that age, and crimes that were committed before one's 18th birthday will not show up in publicly available records regardless of current age, we rely on survey information as our primary source of incarceration outcomes. Of the three youth that were reported as incarcerated and were over 18 at the time of first contact, we were able to confirm one using common incarceration databases. No other youth in the sample were matched to records in these databases.
} 
of light exercise, the frequency of vigorous exercise, and having a dental exam in the past year. These measures of health-related behavior are important to the extent that many ailments are not easily detected among teenagers. For instance, while black adults are one and a half times more likely to develop hypertension and diabetes than white adults (Lopes and Port 1995), the rates of these diseases among black and white youth are roughly the same (Liese et al. 2006). However, many risk factors for both hypertension and diabetes, such as childhood obesity and youth dietary patterns, are more prevalent in black youth.

The remainder of the survey explores three potential exploratory theories that may explain any impacts of the Promise Academy. First, we explore the importance of non-cognitive skills by assessing self esteem, persistence, and locus of control. Second, we measure differences in peer networks by asking youth to how important it is for their friends to study, stay in school, and attending class regularly, in addition to whether their friends use drugs, drink alcohol, smoke cigarettes, steal, fight, and join gangs. Finally, we measure changes in discount rates and risk aversion, both common determinants of decision-making in economic models.

\section{Administrative Data}

We augment our in-person survey data with administrative data from the Harlem Children's Zone, NYCDOE, and NSC. The data from the Harlem Children's Zone consist of lottery files from the 2005 and 2006 sixth grade lotteries. To ensure that all youth in the lottery have an equal chance of being admitted to the Promise Academy, we drop entrants with a sibling that received a winning lottery number in a previous year, as these entrants are automatically admitted. Entrants with a sibling entered in a Promise Academy in the same year are included in our analysis, although we control for the fact that these entrants have a higher probability of admission due to potential admission through sibling preference. Results are identical dropping all siblings. When youth enter more than one lottery, we only include them in the first lottery cohort. A typical student's data include her name, birth date, parents' or guardians' names, home address, and lottery outcome. Following Dobbie and Fryer (2011a), we define lottery winners as youth who receive a winning lottery number or whose waitlist number was below the average highest number called across both years. These lottery winners are admitted to both the Promise Academy middle and high schools simultaneously.

Table 1 presents enrollment outcomes for our lottery sample. Sixty-three percent of lottery winners attend the Promise Academy for at least one year, with 42 percent of lottery winners 
attending the Promise Academy high school for at least one year. The typical lottery winner attends the Promise Academy schools for 2.767 years, 2.540 more years than the typical lottery loser.

The NYCDOE data contain student-level administrative data on approximately 1.1 million students across the five boroughs of the NYC metropolitan area. The data include information on student race, gender, free and reduced-price lunch eligibility, behavior, attendance, matriculation for all students, state math and English Language Arts (ELA) test scores for students in grades three through eight, and Regents test scores for high school students. The data also include a student's first and last name, birth date, and address. We have complete NYCDOE data spanning the 2003-2004 to 2011-2012 school years, with test score and basic demographic data available from the 1999-2000 school year onwards. Thus, we observe all high school outcomes for the 2005 lottery cohort and outcomes through 11th grade for the 2006 lottery cohort.

The state math and ELA tests are high-stakes exams conducted every year for third through eighth grade students. All public school students, including those attending charters, are required to take the math and ELA tests unless they are medically excused or have a severe disability. We normalize test scores to have a mean of zero and a standard deviation of one for each grade, subject, and year across the entire New York City sample.

Regents Exams are statewide subject examinations required for high school graduation. In order to graduate, students must score 65 or higher on Global History and Geography, U.S. History and Government, Comprehensive English, at least one math exam, and at least one science exam. To receive Advanced Designation, students must pass all of exams required for graduation, along with two additional math exams and a second science exam. We create two measures to capture general performance on Regents. Our first measure is the total number of Regent exams passed. The second is the average score on the Living Environment, Global History, and Integrated Algebra exams standardized to have a mean of zero and standard deviation of one in the entire New York City sample. These are the only three Regents exams taken by over 70 percent of both lottery winners and lottery losers. If youth are missing one or two of these exams, we impute the mean score in the lottery sample when calculating the average. Results are nearly identical dropping these youth or calculating the average score only on taken exams. Web Appendix Table 1 presents estimates on taking each exam, passing each exam, and exam score conditional on taking.

The HCZ data were matched to the New York City administrative data using name and date of birth. We were able to match 95.8 percent of lottery winners to the NYC data $(\mathrm{N}=189)$, and 
95.1 percent of lottery losers $(\mathrm{N}=410)$. Our match rates and attrition are similar to previous work using charter lottery data (e.g. Hoxby and Muraka 2009, Angrist et al. 2010, Angrist et al. 2011, Curto and Fryer forthcoming, Dobbie and Fryer 2011b, Abdulkadiroglu et al. 2011). Additional information on the match rates and attrition for each lottery cohort are available in Table 1, with additional details on the match procedure available in Web Appendix B.

To explore the impact of HCZ attendance on college outcomes, we also match the lottery admissions records to information on college attendance from the National Student Clearinghouse (NSC), a non-profit organization that maintains enrollment information for nearly every college and university in the country. The NSC data contain information on enrollment and degrees granted for each college that a student attends. The Promise Academy lottery data were matched to the NSC database by NSC employees using each student's full name, date of birth, and high school graduation date. Youth who are not matched to the NSC database are assumed to have never enrolled in college, including one (unknown) student whose record was blocked by her school. NSC data is available for the entire 2005 lottery cohort.

Columns 1 through 4 of Table 2 present summary statistics for baseline characteristics for our lottery sample and two comparison populations. We report separate sample means for all NYC students who were enrolled in 5th grade in the 2004-05 or 2005-06 school year, all such students who live in the HCZ neighborhood, lottery winners, and lottery losers. Eighty-four and a half percent of lottery entrants are black, compared to 32.8 percent of NYC fifth graders and 63.7 percent of neighborhood fifth graders. Promise Academy lottery entrants under-perform the City average on math and ELA tests by roughly a quarter of a standard deviation. Lottery entrants score marginally higher than their neighbors, but the difference is not statistically or economically significant. Taken together, these summary statistics suggest that the Promise Academy serves a disproportionately black population whose academic performance is similar to students in their geographic area.

\subsection{Research Design}

We estimate two empirical models - Intent-To-Treat (ITT) effects and Local Average Treatment Effects (LATEs) - which provide a set of causal estimates of the impact of attending a highperforming charter school on medium-term outcomes. The ITT estimates measure the causal effect of winning the Promise Academy admissions lottery by comparing the average outcomes of youth 
who 'won' the lottery to the average outcomes of youth who 'lost' the lottery:

$$
\text { outcome }_{i}=\mu+\gamma X_{i}+\pi Z_{i}+\sum_{j} \nu_{j} \text { Lottery }_{i j}+\sum_{j} \phi_{j} \text { Lottery }_{i j} * 1\left(\text { sibling }_{i}\right)+\eta_{i}
$$

where $Z_{i}$ is an indicator for winning an admissions lottery, and $X_{i}$ includes controls for gender, race, 5 th grade special education status, eligibility for free or reduced-price lunch, receipt of Limited English Proficiency (LEP) services, and a quadratic in two prior years of math and ELA test scores. Lottery $_{i j}$ is an indicator for entering the middle school lottery in year $j$, and $1\left(\right.$ sibling $\left._{i}\right)$ indicates whether student $i$ had a sibling enter a Promise Academy lottery in the same year. Equation (1) identifies the impact of being offered a chance to attend the Promise Academy, $\pi$, where the lottery losers form the control group corresponding to the counterfactual state that would have occurred for youth in the treatment group if they had not been offered a spot in the charter school.

Under several assumptions (that the lottery outcomes are random, that winning the lottery does not prevent anyone from attending who would have otherwise enrolled, and that being selected affects outcomes through its effect on Promise Academy enrollment), we can also estimate the causal impact of attending the Promise Academy. This parameter, commonly known as the Local Average Treatment Effect, measures the average effect of attending the Promise Academy on youth who attend the school as a result of winning the admissions lottery (Angrist and Imbens 1994). The LATE parameter can be estimated through a two-stage least squares regression of student achievement on an indicator variable for having ever attended the Promise Academy $\left(P A_{i}\right)$, using the lottery offer $Z_{i}$ as an instrumental variable for the first-stage regression. The second-stage equations for the two-stage least squares estimates therefore take the form:

$$
\text { outcome }_{i}=\mu+\gamma X_{i}+\pi P A_{i}+\sum_{j} \nu_{j} \text { Lottery }_{i j}+\sum_{j} \phi_{j} \text { Lottery }_{i j} * 1\left(\text { sibling }_{i}\right)+\eta_{i}
$$

and the first stage equation is:

$$
P A_{i}=\alpha+\delta X_{i}+\lambda Z_{i}+\sum_{j} \theta_{j} \text { Lotter }_{i j}+\sum_{j} \iota_{j} \text { Lottery }_{i j} * 1\left(\text { sibling }_{i}\right)+\kappa_{i}
$$

where $\lambda$ measures the impact of the lottery offer on the probability of attending the Promise Academy. There is a powerful first-stage effect of winning the lottery on Promise Academy enrollment. Table 2 shows that 63.2 percent of lottery winners attend the Promise Academy at some 
point, compared to 6.5 percent of lottery losers. The typical lottery winner attends the Promise Academy for 2.8 years, over 2.5 more years than the typical lottery loser.

One potential threat to a causal interpretation of our estimates is that the Promise Academy admissions offer is not random $\left(E\left[\eta_{i} \mid Z_{i}\right] \neq 0\right)$. We evaluate this possibility in column 5 of Table 2 by examining observed differences between lottery winners and lottery losers in the NYCDOE data. Lottery winners are 8.8 percentage points less likely to be female in the NYC sample. There are no other statistically significant differences between lottery winners and lottery losers, and a joint F-test that all coefficients are equal to zero has a p-value of 0.789 .

A second threat to our interpretation of the estimates is that lottery entrants may have selectively responded to our survey. In particular, one may be concerned that lottery winners were 11.8 percentage points more likely to respond (see Table 1 ). If lottery losers who did not respond to our survey differ in some important way, this could invalidate our empirical design by creating unobserved differences between the treatment and control groups. We investigate selection into the survey sample in three ways: (1) measuring observed differences between lottery winners and lottery losers in the survey sample, (2) correlating survey response with baseline characteristics for lottery winners and lottery losers, and (3) correlating survey response with observed administrative outcomes for lottery winners and lottery losers.

Column 8 of Table 2 reports the difference between lottery winners and lottery losers in our survey sample following our results from column 5. Lottery winners in the survey sample are 10.8 percentage points less likely to be female, and 1.2 percentage points less likely to be white. There are no other statistically significant differences between lottery winners and lottery losers in the survey sample, and a joint F-test that all differences are equal to zero has a p-value of 0.389 . Taken together with our results from column 5 of Table 2, these results suggest that selection into the survey sample is similar for lottery winners and lottery losers.

Panel A of Table 3 explores selection into our survey sample further by reporting results from a series of regressions of an indicator for survey response on baseline characteristics. The sample is restricted to lottery entrants in the survey pool who we are able to match to the NYCDOE data. All regressions include cohort fixed effects, an indicator for having a sibling in the same lottery, and a sibling-by-cohort interaction. Column 1 reports regression results for the pooled sample of lottery entrants. The coefficients are all small and statistically insignificant, and a joint F-test of all of the listed variables are equal to zero has a p-value of 0.867 . These results suggest that baseline characteristics are not systematically associated with survey response. 
Columns 2 and 3 reports results of the same regression estimated separately for lottery winners and lottery losers, and Column 4 reports the difference between lottery winners and lottery losers. Lottery winners eligible for LEP at baseline are 50.8 (28.8) percentage points less likely to respond to the survey compared to lottery losers eligible for LEP, and lottery winners missing a 5th grade ELA score are 62.4 (30.5) percentage points more likely to respond than lottery losers missing an ELA score. There are no other significant differences between lottery winners and lottery losers, however, and a joint F-test of the individual differences yields a p-value of $0.163 .^{8}$

Panel B of Table 3 reports results correlating survey response with administrative outcomes that are available for both respondents and non-respondents. By examining survey response along realized outcomes, we are able to determine whether survey response differs by changes in outcomes not predicted by baseline characteristics. The administrative outcomes available for this test include eighth grade math scores, eighth grade ELA scores, and college enrollment. In the pooled sample, a one $\sigma$ increase in eighth grade math scores is associated with a 4.9 (2.3) percentage point increase in the probability of response, and college enrollment is associated with a 20.7 (4.8) percentage point increase in survey response. Columns 2 and 3 present results for lottery winners and lottery losers separately, and column 4 reports the difference between the two groups. There is nearly identical selection into the survey sample among lottery winners and lottery losers. None of the individual differences are statistically significant, and a joint F-test on the null that all three differences are equal to zero yields a p-value of 0.808 . Thus, while there is positive selection into our survey sample based on realized outcomes, there is no evidence that lottery winners and lottery losers differentially select into the survey sample.

\section{Analysis}

\subsection{Main Outcomes}

We estimate the impact of the Promise Academy in the Harlem Children's Zone on human capital outcomes, risky behaviors, and physical and mental health.

\section{A. Human Capital}

\footnotetext{
${ }^{8}$ In results available upon request, we correlate survey response with predicted outcomes using baseline variables. Consistent with the results from Table 2 and Panel A of Table 3, there are no significant predictors of survey response among lottery winners or lottery losers. There are also no statistically significant differences between the lottery winners and lottery losers, and a joint F-test on the null that all five differences are equal to zero yields a p-value of 0.987 .
} 
Dobbie and Fryer (2011a) find that Promise Academy students gain $0.229 \sigma$ in math and $0.047 \sigma$ in ELA per year on the required state exams. To provide evidence on whether these state test score gains reflect increases in general knowledge and skills, as opposed to test-specific skills, we estimate the impact of the Promise Academy on a number of alternative measures of human capital.

Panel A of Table 4 presents ITT and LATE estimates of the impact of the Promise Academy on human capital outcomes. Woodcock-Johnson results include lottery entrants who responded to the survey and complete the indicated Woodcock-Johnson test. Results are statistically identical restricting to respondents who answered every survey question. High school Regents results include lottery entrants who attend a NYC high school for at least one year, while college enrollment results include all 2005 lottery entrants. Each regression controls for the demographic variables listed in Table 2, lottery effects, sibling by lottery effects, and a quadratic in 4th and 5th grade math and ELA scores. We report standard errors that are robust to arbitrary heteroskedasticity in all regressions. Note: Each regression throughout the paper includes all available students for that outcome to maximize sample size. ${ }^{9}$

Lottery winners score $0.283 \sigma(0.083)$ higher than lottery losers on the math portion of the Woodcock-Johnson test, and $0.119 \sigma(0.083)$ higher on the reading portion. Youth who attend the Promise Academy due to a winning lottery draw score $0.439 \sigma(0.121)$ higher in math and $0.185 \sigma(0.123)$ higher in reading. Attending the Promise Academy has the largest impact on Math Calculation, with Promise Academy students scoring 0.595 $(0.127)$ higher than they otherwise would have. Promise Academy students also score 0.366 $\sigma$ (0.153) higher in Math Fluency, and $0.325 \sigma(0.138)$ higher on Letter-Word Identification. The estimated impacts on the other sub-test results are not statistically significant.

Lottery winners also take more New York State Regents exams and score higher on the exams that most students take. ${ }^{10}$ Lottery winners pass 1.115 (0.277) more Regents exams than lottery losers, a 31 percent increase from the control mean of 3.571 exams. On the three core exams that over 70 percent of lottery winners and lottery losers take - Living Environment, Global History, and Integrated Algebra - lottery winners score $0.270 \sigma$ (0.089) higher than lottery losers. The gains are largest in Integrated Algebra, where lottery winners score $0.477 \sigma(0.099)$ higher (see Web Appendix

\footnotetext{
${ }^{9}$ Restricting all regressions to have a common sample does not qualitatively change our results.

${ }^{10}$ Selection into the Regents exams complicates the interpretation of these estimates. If, for example, the Promise Academy pushes weaker students to take harder Regents exams, then our results are likely to be too conservative. Consistent with this, Web Appendix Table 1 shows that lottery winners are at least as likely to take each exam except Comprehensive English, and are more likely to take and pass advanced subjects like Geometry, Physics, and Chemistry.
} 
Table 3). Lottery winners are also 20.3 (4.9) and and 12.6 (4.1) percentage points more likely to take the more advanced Geometry and Chemistry exams, and, conditional on taking these exams, score $0.472 \sigma(0.118)$ and $0.496 \sigma(0.236)$ higher.

Our final measure of human capital is college enrollment. College enrollment outcomes are limited to the 2005 lottery cohort, as the 2006 cohort will not graduate high school until the spring of 2013. Lottery winners are 14.1 (6.1) percentage points more likely to enroll in college the fall after their senior year, a 49.0 percent increase from the control mean of 28.8 percent. Attending the Promise Academy increases the probability of enrolling in college by 24.2 (9.7) percentage points, an 84 percent increase. In Appendix Table 2, we show that lottery winners are also 21.3 (5.9) percentage points more likely to attend a four-year college and 7.2 (2.3) percentage points less likely to attend a two-year college. These results are consistent with the Promise Academy inducing at least some students to enroll in a four-year college instead of a two-year school. Appendix Table 2 also shows that lottery winners are 4.5 (3.8) percentage points more likely to enroll at a college where the average student has SAT scores of 1,000 points or higher (out of 1,600), but the point estimate is not statistically significant.

We summarize the impact of the Promise Academy on human capital using an index measure that combines all five individual human capital measures. To construct the index, we standardize each individual measure to have a mean of zero and a standard deviation of one in the control group. We then take the average of each standardized z-score measure. We include all youth with at least one non-missing outcome. The impact of winning the admissions lottery on this human capital index measure is $0.277 \sigma(0.068)$, suggesting a large and precisely estimated impact of the Promise Academy on non-test score skills.

\section{B. Risky Behaviors}

Panel B of Table 4 presents estimates of the impact of the Promise Academy on teen pregnancy, incarceration, self-reported drug and alcohol use, and self-reported criminal behavior. Pregnancy results include all female survey respondents, while self-reported results include all survey respondents who answered the relevant question. Results are statistically identical restricting the sample to respondents who answered every survey question. The incarceration results include the 234 male lottery entrants whom we successfully contacted, regardless of whether or not they completed a survey. We define incarceration as currently being in jail or prison when we contacted the lottery entrant. Following Panel A, each regression controls for the demographic variables listed in Table 
2, lottery effects, sibling by lottery effects, and a quadratic in 4th and 5th grade math and ELA test scores. Standard errors have been adjusted to account for arbitrary heteroskedasticity.

Seventeen percent of female lottery losers report having been pregnant at some point. In comparison, 10.0 percent of minority women and 10.4 percent of low-income women in New York City schools give birth in their teens (Chetty, Friedman, and Rockoff 2011). Female lottery winners are 12.1 (4.6) percentage points less likely to report that they have ever been pregnant, a 71 percent reduction from the control mean. ${ }^{11}$

Four percent of male lottery losers were incarcerated during our sample period, compared to none of the male lottery winners. One female lottery loser and one female lottery winner were also incarcerated during our sample period. ${ }^{12}$ In our ITT framework, male lottery winners are 4.3 (1.8) percentage points less likely to be incarcerated, essentially a one hundred percent decrease. To put this estimate in context, Deming (2011) finds being offered a spot at a student's first choice public school in Charlotte-Mecklenburg decreases the probability of spending at least 90 days in jail over the next five years by 10.7 percentage points for males in the highest risk quintile, a 81.1 percent drop. The effect decreases to 8.4 percentage points, or 53.8 percent, six years after the school choice lottery.

We find little evidence that the Promise Academy impacts self-reported drug and alcohol use or self-reported criminal behavior. Lottery winners are $0.016 \sigma(0.111)$ less likely to report using drugs and alcohol, and $0.012 \sigma(0.064)$ less likely to report criminal behavior, with neither estimate close to statistical significance. The results are similar if estimate effects for males and females separately. There are at least three possible explanations for the positive impact on administrative outcomes and no effect on self-reported outcomes. First, our self-reported measures are likely biased downwards due to the fact that incarcerated youth are unable to respond to our survey. Second, there may be underreporting of risky behavior that masks a true treatment effect. For instance, youth in the MTO follow-up study under report criminal behavior by 15 to 20 percent, with treated youth only slightly less likely to self-report crime (Kling, Ludwig, and Katz 2005). Finally, it is possible that criminal behaviors are the same, but that lottery winners are less likely to be caught.

\footnotetext{
${ }^{11}$ We also asked survey respondents about various self-reported sexual habits which might explain the effect on pregnancy. As the results in Panel D of Appendix Table 7 show, there are no detectable differences in these behaviors. Promise Academy youth are equally likely to have had sex, and are about as likely to have used a condom or another form of contraception during their most recent sexual experience, though we are under-powered to detect modest differences.

${ }^{12}$ Using national samples of men born after 1965, Pettit and Western (2004) estimate that 2.06 percent of black men aged 15 - 19 and 6.06 percent of black men aged 20 - 24 have been incarcerated at least once. Equivalent figures for white men are 0.39 percent and 0.73 percent.
} 
Following our human capital results in Panel A, we summarize the impact of the Promise Academy on risky behavior using an index measure that combines all four individual measures. Lottery winners are $0.135 \sigma(0.072)$ less likely to engage in risky behavior according to our index measure. The result is driven by the incarceration and pregnancy results, as there is relatively little variation across students in the self-reported measures.

\section{Health}

Panel C of Table 4 presents estimates of the impact of the Promise Academy on healthy eating, mental health, physical health, and an index of surveyed health behaviors. Each regression includes all survey respondents who answered the indicated question, and follows the same specification as Panels A and B. Results are statistically identical restricting the sample to respondents who answered every survey question.

Lottery winners are $0.108 \sigma(0.061)$ more likely to report healthy eating habits, yet these habits do not appear to have translated into improvements on any other health outcomes. Lottery winners self-report physical health that is $0.050 \sigma(0.063)$ lower, with no discernible effects on asthma attacks, obesity, or self-reported health. Lottery winners also report mental health that is $0.034 \sigma(0.103)$ lower than lottery losers. Our summary index of both physical and mental health is $0.032 \sigma(0.057)$ higher for lottery winners as compared to lottery losers.

\subsection{Robustness Checks}

In this section, we explore the robustness of our results to two potential threats to validity: (1) differential attrition from the survey sample, and (2) false positives due to multiple hypothesistesting.

First, we consider the extent to which sample attrition threatens our estimates by calculating Lee (2009) bounds and imputing outcomes for youth who did not respond to the survey. Panel A of Table 5 presents these results for the administrative outcomes that are available for all lottery entrants. Column 1 presents standard ITT estimates using the full sample of lottery entrants as reported in column 2 of Table 4 . Column 2 restricts the sample to lottery entrants in the survey sample to explore the extent of any attrition bias on these outcomes. The impact of being offered admission to the Promise Academy is similar in the full and survey samples across all of our administrative outcomes. Lottery winners score $0.446 \sigma$ (0.077) higher in math in the full sample and $0.466 \sigma(0.081)$ higher in the survey sample. ELA scores are $0.156 \sigma(0.057)$ higher in the full 
sample and $0.132 \sigma(0.055)$ higher in the survey sample. The effect on the number of Regents exams passed is 0.174 higher in the survey sample, the effect on Regents scores is $0.003 \sigma$ lower, and the impact on college enrollment is 1.4 percentage points higher. These results suggest that there is, at worst, modest upwards bias in the survey sample, likely due to the fact that the first stage impact of a lottery offer on Promise Academy enrollment is approximately 11 to 15 percent larger in the survey sample (see Table 2).

Column 3 of Panel A reports the Lee (2009) bound for each administrative outcome. Each bound is calculated by dropping the fraction of the highest-achieving lottery winners necessary to equalize the response rate among lottery winners and lottery losers. Specifically, we drop the lottery winners with the highest residuals from our main estimating equation. In this worst case scenario, there is still a statistically significant effect of the Promise Academy on two out of five of our administrative outcomes, with lottery winners scoring $0.098 \sigma(0.069)$ higher on our human capital index compared to lottery losers. In each case, the Lee (2009) bounds are much lower than the true ITT estimates from column 1.

Column 5 presents results imputing outcomes for non-respondents. We impute outcomes for all non-survey respondents, including lottery winners, using the baseline characteristics listed in Table 2 and the administrative outcomes available for all lottery entrants. Our results in column 5 show that the imputation results are downwards biased relative to the true ITT estimates in column 1, suggesting that these results are also a conservative approach to dealing with attrition in our sample.

Panel B reports Lee (2009) bounds and imputation results for our survey outcomes. The only Lee (2009) bound that is statistically significant in our survey outcomes is pregnancy, though due to large standard errors we cannot rule out the bounds and the survey estimates being statistically identical. We are also unable to calculate a bound for incarceration, as there are no incarcerated males in the treatment group. Conversely, our imputation results in column 5 are nearly identical to our results reported in Table 4. None of the results lose statistical significance, and none are statistically different than the reported results from Table 4.

A second concern is that we are detecting false positives due to multiple hypothesis-testing. Appendix Table 3 presents results controlling for the Family-Wise Error Rate, using an algorithm similar to those described by Westfall and Young (1993), Kling, Liebman, and Katz (2007), and Anderson (2008). For a given family of $k$-hypothesis tests, the algorithm estimates the probability that the observed t-statistic is larger than the equivalently-ranked test statistic that would be 
generated by random chance. Web Appendix E provides a full description of how we implemented this procedure.

Appendix Table 3 confirms the robustness of our main findings. The p-value on the human capital index remains less than 0.001 after adjusting for multiple-hypothesis testing, while the p-value on the risky behavior index rises from 0.063 to 0.123 . The more conservative Bonferroni correction, which controls the family-wise error rate under the assumption that all test statistics are independent, is calculated by multiplying the per-comparison p-values by the number of hypothesis tests. Thus, the Bonferroni corrected p-value on the human capital index is 0.0002 , and the Bonferroni corrected p-value on the risky behavior index rises to 0.190 .

\section{Interpretation}

\subsection{Neighborhoods vs. Schools}

In addition to the school investments typical of a high-performing charter school, Promise Academy students are exposed to a network of community services in the Harlem Children's Zone. The community programs may plausibly impact future outcomes by providing a more supportive outof-school learning environment.

To fix ideas, consider a model of education production where student achievement is a function of school inputs $(s)$, community inputs $(c)$, and a vector of other inputs such as parental involvement, student motivation, and so on $(\bar{x})$. For simplicity, we assume $f(s, c, \bar{x})$ is $C^{2}$ in all its arguments and additively separable. We use this simple apparatus to investigate three pieces of evidence to better understand the empirical importance of the HCZ neighborhood programs and the Promise Academy school investments.

\section{A. Inside V. Outside HCZ}

First, following Dobbie and Fryer (2011a), we estimate treatment effects separately for youth living within 400 meters of the original 24-block Harlem Children's Zone (inside HCZ), who are more likely to receive neighborhood benefits, and youth living more than 400 meters away (outside HCZ), who are less likely to receive neighborhood benefits. Treatment effects for youth living inside the zone provide estimates of $\frac{\partial f}{\partial s}+\frac{\partial^{2} f}{\partial s \partial c}$. Treatment effects for youth living outside the zone provide estimates of $\frac{\partial f}{\partial s}$. If the two estimates are similar, this implies $\frac{\partial^{2} f}{\partial s \partial c} \approx 0$. 
An important assumption in this approach is that youth who live inside $\mathrm{HCZ}$ are significantly more likely to participate in neighborhood programs, relative to youth who live outside the HCZ. To partially test whether address is associated with community program exposure, we collected administrative data from $\mathrm{HCZ}$ on participation in the neighborhood programs. The data consists of "sign-in" sheets maintained by six of the largest HCZ programs: the College Success counseling program, the Cut Above after-school program, the Employment and Technology Center, the Learn to Earn after-school program, the Peacemakers neighborhood safety program, and the Truce Fitness and Nutrition Center. Each data file includes the participant's name, date of birth, program, and date of participation, and spans the 2006 through 2009 fiscal years. We linked these data to the lottery files at HCZ using name and date of birth.

These "sign-in" data confirm that address is strongly associated with participation in neighborhood programs. Fifty-one percent of lottery winners living inside HCZ participated in at least one neighborhood program, as do 57 percent of lottery losers inside HCZ. In contrast, 23 percent of lottery winners and 31 percent of lottery losers living outside of HCZ participated in at least one neighborhood program. The original 24-block HCZ plus 400 meters is more predictive of program participation than the expanded 97-block HCZ, likely because the neighborhood programs are still concentrated around the original HCZ. All of the reported results are consistent to alternative definitions of inside HCZ.

Table 6 presents these ITT estimates for youth living in and outside HCZ. We drop students with no baseline address information. Consistent with Dobbie and Fryer (2011a), there are no statistically different effects by HCZ residence for any of our summary indices. Lottery winners living in HCZ have human capital scores that are $0.281 \sigma(0.124)$ higher than lottery losers in the Zone, while lottery winners living outside the Zone have human capital scores that are $0.268 \sigma$ (0.077) higher. Lottery winners in the Zone also are $0.127 \sigma(0.103)$ less likely to engage in risky behaviors, and are $0.045 \sigma(0.094)$ healthier than lottery losers in the Zone. In comparison, lottery winners out of the Zone are $0.135 \sigma$ (0.077) less likely to engage in risky behaviors and $0.034 \sigma$ (0.062) healthier than lottery losers out of the Zone.

Further, Appendix Table 4 presents estimates for the individual index components for students living inside and outside HCZ. There are no statistically significant differences between the in and outside of $\mathrm{HCZ}$ treatment estimates for the 15 point estimates we consider, with many of the estimates larger for youth living outside of HCZ. 


\section{B. Additional High-Performing Charter Schools}

To provide a second piece of evidence on the empirical importance of neighborhood versus school investments, we attempted to collect admissions lottery data from a number of high-performing charter high schools that explicitly do not have community investments as a part of their strategy, but who have school inputs similar to the Promise Academy. In other words, the forthcoming estimates will identify $\frac{\partial f}{\partial s}$ from an alternative sample of schools.

In the spring of 2013, we approached 16 charter schools identified by the Charter School Growth Fund - a non-profit that attempts to help the highest performing charter schools expand - as particularly high-performing schools with at least one cohort of students in college. Eligible schools were invited to participate via email and phone. We also hosted two informational webinars to explain the project to interested schools. Schools were offered a $\$ 5000$ stipend to be received conditional on providing all of the appropriate lottery data. Of the 16 eligible charter schools, seven schools agreed to participate. Of these seven schools, three were able to provide the required admissions lottery information: the Denver School of Science and Technology, the Noble Network of Charter Schools, and the Summit Preparatory High School in Redwood City, California. A fourth school - the Match Charter School of Boston - was a previous research partner and also agreed to participate in the study. To explore the impact of these schools on college outcomes, we matched the lottery admissions records to information on college attendance from the NSC using each student's full name, date of birth, and high school graduation date. Appendix Table 6 and Appendix F further describes the data available for each school.

Table 7 presents ITT and LATE estimates of the impact of these four high-performing charter high schools on college enrollment outcomes. Each regression controls for gender, lottery effects, and sibling by lottery effects. Lottery winners are 4.9 (1.4) percentage points more likely to enroll in college, a 9.2 percent increase from the control mean of 53.0 percent. Attending a high-performing charter high school increases the probability of enrolling in college by 8.8 (2.5) percentage points, a 16.6 percent increase. Lottery winners are also $6.3(1.4)$ percentage points more likely to attend a four-year college but no more likely to attend a two-year college. These results are consistent with our earlier results showing that the Promise Academy induces at least some students to enroll in a four-year college instead of a two-year school. Table 7 also shows that lottery winners are 6.3 (1.3) percentage points more likely to enroll at a college where the average student has SAT scores of 1,000 points or higher (out of 1,600).

These data provide suggestive evidence that schools may be enough to increase college enroll- 
ment among poor urban students. It is important to note, however, that the control mean in this sample of schools has college enrollment rates similar to the treatment mean of Promise Academy students. This leaves open the possibility that the student populations in the HCZ and those who attend other high-performing charter schools are not directly comparable.

\section{A Comparison with the Moving to Opportunity Experiment}

To provide a final piece of evidence on this issue, Appendix Table 5 compares the effects of the Promise Academy with that of the Moving to Opportunity (MTO) intervention that relocated individuals from high-poverty to lower-poverty neighborhoods while keeping the quality of schools roughly constant (e.g. an estimate of $\frac{\partial f}{\partial c}$ ). We use estimates from Kling, Liebman, and Katz (2007), who evaluate the impact of MTO four to seven years after random assignment for youth who are 15 to 20 years old. ${ }^{13}$ Recall that our analysis estimates the impact of the Promise Academy five to six years after random assignment for youth who are 17 to 21 years old. We also follow Kling, Liebman, and Katz (2007) and present ITT estimates separately by gender.

The comparison with the MTO estimates suggests little overlap in the effects of neighborhood quality compared to school quality. The Promise Academy significantly increases WoodcockJohnson math scores for both males and females, while MTO has no impact, particularly for males. The Promise Academy also significantly decreases teen pregnancy, while MTO appears to have no effect. Conversely, MTO increases mental health by $0.289 \sigma(0.094)$ for females, while there is no impact of the Promise Academy on this measure for either males or females.

\subsection{Test Scores and Later-Life Outcomes}

This section considers the extent to which changes in test scores might explain the impact of the Promise Academy on non-test score outcomes. Specifically, we compare the reduced form estimates of the impact of the Promise Academy on non-test score outcomes to the effects implied by the cross-sectional relationship between test scores and non-test score outcomes in Chetty, Friedman, and Rockoff (2011) and the control group.

Chetty, Friedman, and Rockoff (2011) find that a one $\sigma$ increase in math or ELA achievement is associated with a 5.6 percentage point increase in college attendance at age 20 for minorities, and

\footnotetext{
${ }^{13}$ Sanbonmatsu et al. (2011) and Gennetian et al. (2012) report MTO results ten to 15 years after random assignment. The results are qualitatively similar to those reported by Kling, Liebman, and Katz (2007).
} 
a 5.2 percentage point increase for students from low-income families. A one $\sigma$ increase in math or ELA achievement is also associated with a 1.2 percentage point decrease in teen pregnancy among both minority women and women from low-income families. The impact of the being offered admission to the Promise Academy in the survey sample is $0.466 \sigma$ in eighth grade math and $0.132 \sigma$ in eighth grade ELA. Using the average correlation across minorities and low-income families from Chetty, Friedman, and Rockoff (2011), these estimates imply that the test score effect alone would lead to a $(5.4 \cdot(0.466+0.132))=3.3$ percentage point increase in college enrollment and a $(1.2 \cdot(0.466+0.132))=0.7$ percentage point decrease in teen pregnancy. Using the ITT estimates in Table 4, this implies that the eighth grade test score increase can explain $((3.2 / 14.1) \cdot 100)=23.1$ percent of the college enrollment effect, and $((0.7 / 12.1) \cdot 100)=6.1$ percent of the pregnancy effect.

We can perform a similar exercise using the correlations identified within the lottery losers. Following Chetty, Friedman, and Rockoff (2011), we estimate correlations based on math and reading scores from grades four through eight. We stack observations such that each row is a unique student-subject-grade combination, and identify the correlation between scores and outcomes after controlling for our full set of demographic variables and a cubic in previous year's test scores. The correlations that we identify are larger than those estimated by Chetty, Friedman, and Rockoff (2011), though not large enough to explain the reduced form effects on non-test score outcomes. A one $\sigma$ increase in math or ELA test scores is associated with a 12.4 percentage point increase in college enrollment, a 6.9 percentage point reduction in teen pregnancy, and a 1.5 percentage point reduction in the likelihood of being incarcerated. These correlations imply that the eighth grade test score increase can explain $(12.4 \cdot(0.466+0.132) / 14.1 \cdot 100)=52.6$ percent of the college enrollment effect, $(6.9 \cdot(0.466+0.132) / 12.1 \cdot 100)=34.1$ percent of the pregnancy effect, and $(1.5 \cdot(0.466+0.132) / 4.1 \cdot 100)=20.8$ percent of the incarceration effect. Large standard errors on the cross-sectional estimates means that we cannot rule out much larger and smaller impacts.

\subsection{Other Mechanisms}

Our results up until this point suggest that the Promise Academy investments drive the impact on non-test score outcomes, but that the impacts are significantly larger than what would be implied by the cross-sectional relationship between test scores and later outcomes. This section considers three alternative mechanisms: (1) non-cognitive skills, (2) social networks, and (3) economic preference parameters.

A large body of evidence suggests that non-cognitive skills, such as self-esteem, locus of control, 
and persistence, are correlated with later outcomes. Self-esteem is thought to influence teenage pregnancy and drug use (Stewart et al. 1995, Kalil and Kunz 1999, Cornelius et al. 2004), although there is considerable disagreement on these points (McGee and Williams 2000, Paul et al. 2000). Persistence, as measured through the 8-item scale we use in this paper, is associated with educational attainment and fewer career changes among adults and increased GPA and reduced grade retention among adolescents (Duckworth and Quinn 2009). Heckman et al. (2006) show that self-esteem and locus of control are related to earnings, incarceration, and teen pregnancy. We test this mechanism by administering the Rosenberg self esteem index, which asks respondents to rate the extent to which they agree to a series of 14 statements such as "I certainly feel useless at times" and "At times, I think I am no good at all" (Rosenberg 1965). Youth were also asked to answer questions from the Rotter Locus of Control instrument, which measures the extent to which respondents believe they control events in their lives (Rotter 1966).

Panel A of Appendix Table 7 presents results of the impact of the Promise Academy on these non-cognitive skills. If anything, Promise Academy students report lower non-cognitive skills than the control group. Lottery winners score $0.138 \sigma$ (0.110) lower on the Rosenberg self esteem index, and $0.254 \sigma(0.113)$ lower on Duckworth and Quinn's (2009) short grit scale, though only the latter is statistically significant. Lottery winners have Locus of Control scores that are $0.041 \sigma(0.107)$ higher, but the estimate is not statistically different than zero. ${ }^{14}$

The second mechanism we explore is the impact of the Promise Academy on traditional economic preference parameters such as risk aversion and discount rate. These measures are the common determinants of decision-making in economic models and have been linked to a variety of later outcomes (Borghans et al. 2008). Discount rates and risk aversion are measured by asking youth to make choices through a fixed series of comparisons to infer an indifference point (Hardisty et al. 2011). For discount rates, youth were asked whether they would prefer that $\$ 40$ to be mailed to them later that day or for a larger amount to be mailed in one month. The amount was then varied until the student changed her answer or reached the extreme value of either $\$ 42$ or $\$ 55$. For risk aversion, youth were given a choice between a job that paid $\$ 600$ with probability one and a second identical job that paid $\$ 1,200$ with probability 0.5 and a value less than $\$ 600$ with equal

\footnotetext{
${ }^{14}$ The negative impact of the Promise Academy on self esteem and grit may be the result of different reference points regarding hard work and perseverance (Heine et al. 2002, 2008). To partially test this theory, we correlate grit scores with Woodcock-Johnson math scores in the treatment and control groups. The correlation between grit and Woodcock-Johnson math scores is 0.24 in the control group but -0.07 in the treatment group. This pattern of results is inconsistent with the idea that treatment changes reference points by an equal amount, but could be explained by a more complex story in which reference points change more for more students with higher ability.
} 
probability. The latter value was then altered until a student changed her answer or reached an extreme value of either $\$ 150$ or $\$ 540$. To maintain consistency with the rest of our results, we report results for both discount rate and risk aversion in standard-deviation units.

Winning the lottery to attend the Promise Academy has no detectable effect on discount rates. Lottery winners have discount rates that are only $0.045 \sigma(0.110)$ higher. ${ }^{15}$ Conversely, the Promise Academy does seem to alter risk aversion in its students, as lottery winners report $0.248 \sigma(0.103)$ higher Pratt-Arrow measures than lottery losers.

The final mechanism we explore is the importance of changes in peer quality. A large literature suggests that outcomes are heavily influenced by one's peers (Sacerdote 2000, Fergusson et al. 2002, Boisjoly et al. 2006, Carrell et al. 2009, Deming 2011). We measure peer networks by asking youth about the attitudes of their peer group on crime and educational attainment. Academic peer quality was measured by asking youth to how important it is for their friends to study, stay in school, and attending class regularly. Risky behavior peer quality was measured by asking youth whether their friends use drugs, drink alcohol, smoke cigarettes, steal, fight, or are in a gang. We use these responses to create summary indices of peer networks.

Panel C of Appendix Table 7 presents results of the impact of the Promise Academy on peer quality. Lottery winners have peers that are $0.094 \sigma(0.077)$ higher than lottery losers on our index measuring the relative importance of various academic activities in one's peer group, though the effect is not statistically significant. There is almost no difference between levels of risky behaviors in the networks of winners and losers, with an estimated point estimate of $-0.009 \sigma(0.069)$. Taken together, we interpret these results as suggesting that changes in peer quality are not driving our results, although we cannot rule out changes in other forms of social interaction.

\section{Conclusion}

In this paper, we estimate the impact of attending the Promise Academy in the Harlem Children's Zone on a wide range of human capital investments, risky behaviors, and health outcomes. Youth randomly offered admission to the Promise Academy score higher on nationally-normed math achievement tests, are more likely to enroll in college, less likely to be pregnant in their teens, and less likely to be incarcerated. A comparison of youth living in and outside of the Zone reveal

\footnotetext{
${ }^{15}$ Over a third of the sample selected the highest discount rate category, preferring $\$ 40$ now to $\$ 55$ in one month, implying an annual discount rate of over 4,000 percent. We also find no impact of the Promise Academy on choosing the highest discount rate category, or choosing a rate above the median.
} 
similar impacts on these outcomes. The impact of other high-performing charter schools on college enrollment is similar to Promise Academy students - suggesting the results are more general.

The education reform movement is based, in part, on two important assumptions: (1) high quality schools can increase test scores, and (2) the well-known relationship between test scores and adult outcomes is causal. We have good evidence that the first assumption holds (Angrist et al. 2010, Abdulkadiroglu et al. 2011, Dobbie and Fryer 2011a). This paper presents the first pieces of evidence that the second assumption may not only be true, but that the cross-sectional correlation between test scores and adult outcomes may understate the true impact of a high quality school, suggesting that high quality schools change more than cognitive ability. Importantly, the return on investment for high-performing charter schools could be much larger than that implied by the short-run test score increases.

A larger sample of schools, longer-term outcomes, and a better sense of the mechanisms generating the observed impacts are all ripe areas for future research. 


\section{References}

[1] Abdulkadiroglu, Atila, Joshua Angrist, Susan Dynarski, Thomas J. Kane, and Parag Pathak. 2011. "Accountability in Public Schools: Evidence from Boston's Charters and Pilots." Quarterly Journal of Economics, 126(2): 699-748.

[2] Anderson, Michael L. 2008. "Multiple Inference and Gender Differences in the Effects of Early Intervention: A Reevaluation of the Abecedarian, Perry Preschool, and Early Training Projects." Journal of the American Statistical Association, 103: 1481-1495.

[3] Angrist, Joshua D., Sarah R. Cohodes, Susan M. Dynarski, Jon B. Fullerton, Thomas J. Kane, Parag A. Pathak, Christopher R. Walters. 2011. "Student Achievement in Massachusetts' Charter Schools." Center for Education Policy Research at Harvard University.

[4] Angrist, Joshua D., Susan M. Dynarski, Thomas J. Kane, Parag A. Pathak, and Christopher R. Walters. 2010. "Inputs and Impacts in Charter Schools: KIPP Lynn?" American Economic Review Papers and Proceedings, 100:1-5.

[5] Angrist, Joshua D. and Guido Imbens. 1994. "Identification and Estimation of Local Average Treatment Effects." Econometrica, 62(2): 467-475.

[6] Boisjoly, Johanne, Greg J. Duncan, Michael Kremer, Dan M. Levy, and Jacque Eccles. 2006. "Empathy or Antipathy? The Impact of Diversity." American Economic Review, 96(5): 18901905.

[7] Borghans, Lee, Angela Lee Duckworth, James J. Heckman, and Bas ter Weel. 2008. "The Economics and Psychology of Personality Traits." Journal of Human Resources, 43(4): 9721059.

[8] Carter, Samuel C. 2000. "No Excuses: Lessons from 21 High-Performing, High-Poverty Schools." Heritage Foundation.

[9] Carrel, Scott E., Richard L. Fullerton, and James E. West. 2009. "Does Your Cohort Matter? Measuring Peer Effects in College Achievement." Journal of Labor Economics, 27(3): 439-464.

[10] Chetty, Raj, John Friedman, and Jonah Rockoff. 2011. "The Long-Term Impacts of Teachers: Teacher Value-Added and Student Outcomes in Adulthood." NBER Working Paper No. 17699. 
[11] Chetty, Raj, John Friedman, Nathaniel Hilger, Emmanuel Saez, Diane Schanzenbach, and Danny Yagan. 2011. "How Does Your Kindergarten Classroom Affect Your Earnings?" Quarterly Journal of Economics, 126(4): 1593-1660.

[12] Clark, Melissa A., Philip Gleason, Christina Clark Tuttle, and Marsha K. Silverberg. 2011. "Do Charter Schools Improve Student Achievement? Evidence from a National Randomized Study." Mathematica Policy Research, accessed at http://www.mathematica-mpr.com/ publications/PDFs/education/charterschools_WP.pdf

[13] Cornelius, Marie D., Sharon L. Leech, and Lidush Goldschmidt. 2004. "Characteristics of Persistent Smoking Among Pregnant Teenagers Followed to Young Adulthood." Nicotine and Tobacco Research, 6(1): 159-169.

[14] Cullen, Julie Berry, Brian A. Jacob, and Steven Levitt. 2006. "The Effect of School Choice on Participants: Evidence from Randomized Lotteries." Econometrica, 74(5): 1191-1230.

[15] Curto, Vilsa, and Roland G. Fryer. "The Potential of Urban Boarding Schools for the Poor: Evidence from SEED." Forthcoming in the Journal of Labor Economics.

[16] Deming, David J. 2011. "Better Schools, Less Crime?" Quarterly Journal of Economics, 126(4): 2063-2115.

[17] Deming, David J., Justine S. Hastings, Thomas J. Kane, and Douglas O. Staiger. 2011. "School Choice, School Quality, and Postsecondary Attainment." NBER Working Paper No. 17438.

[18] Dobbie, Will, and Roland G. Fryer. 2011a. "Are High-Quality Schools Enough to Increase Achievement among the Poor? Evidence from the Harlem Children's Zone." American Economic Journal: Applied Economics, 3(3): 158-187.

[19] Dobbie, Will, and Roland G. Fryer. 2011b. "Getting Beneath the Veil of Effective Schools: Evidence from New York City." NBER Working Paper No. 17632.

[20] Duckworth, Angela L. and Quinn, Patrick D. 2009. "Development and Validation of the Short Grit Scale (Grit-S).” Journal of Personality Assessment, 91: 166-174.

[21] Fergusson, David M., Nicola R. Swain-Campbell, and L. John Horwood. 2002. "Deviant Peer Affiliations, Crime and Substance Use: A Fixed Effects Regression Analysis." Journal of Abnormal Child Psychology 30(4): 419-430. 
[22] Fryer, Roland G. 2011a. "Racial Inequality in the 21st Century: The Declining Significance of Discrimination." Handbook of Labor Economics Volume 4, Orley Ashenfelter and David Card (eds.).

[23] Fryer, Roland G. 2011b. "Injecting Successful Charter School Strategies into Traditional Public Schools: Early Results from an Experiment in Houston." NBER Working Paper No. 17494.

[24] Gennetian, Lisa A., Matthew Sciandra, Lisa Sanbonmatsu, Jens Ludwig, Lawrence F. Katz, Greg J. Duncan, Jeffrey R. Kling, Ronald C. Kessler. 2012. "The Long-Term Effects of Moving to Opportunity on Youth Outcomes." Cityscape, 14(2): 137 - 168.

[25] Gleason, Philip, Melissa Clark, Christina Clark Tuttle, Emily Dwoyer, and Marsha Silverberg. 2010. "The Evaluation of Charter School Impacts: Final Report." National Center for Education and Evaluation and Regional Assistance, 2010-4029.

[26] Halaydna, Thomas M. 2006. "Perils of Standardized Achievement Testing." Educational Horizons, 85(1): 30-43.

[27] Haladyna, Thomas M., Susan Bobbit Nolen, and Nancy S. Haas. 1991. "Raising Standardized Achievement Test Scores and the Origins of Test Score Pollution." Educational Researcher, $20(5), 2-7$.

[28] Hardisty, David J., Katherine Thompson, David Krantz, and Elke U. Weber. 2011. "How to Measure Discount Rates? An Experimental Comparison of Three Methods." Available at SSRN: http://ssrn. com/abstract $=1961367$

[29] Heckman, James J., and Yona Rubinstein. 2001. "The Importance of Noncognitive Skills: Lessons from the GED testing program." American Economic Review, 91(2), 145-149.

[30] Heckman, James. J., Jora Stixrud, and Sergio Urzua. 2006. "The Effects of Cognitive and Noncognitive Abilities on Labor Market Outcomes and Social Behavior." Journal of Labor Economics, 24(3), 411-482.

[31] Heine, Steven J., Emma E. Buchtel, and Ara Norenzayan. 2008. "What Do Cross-National Comparisons of Personality Traits Tell Us? The Case of Conscientiousness." Psychological Science, 19(4): 309-313. 
[32] Heine, Steven J., Darrin R. Lehman, Kaiping Peng, and Joe Greenholtz. 2002. "What's Wrong with Cross-Cultural Comparisons of Subjective Likert Scales?: The Reference-Group Effect." Journal of Personality and Social Psychology, 82(6): 903-918.

[33] Jacob, Brian A. 2005. "Accountability, Incentives and Behavior: The Impact of High-stakes Testing in the Chicago Public Schools." Journal of Public Economics 89(5-6): 761-796.

[34] Jacob, Brian, and Steven Levitt. 2003. "Rotten Apples: An Investigation of the Prevalence and Predictors of Teacher Cheating." Quarterly Journal of Economics, 117(3): 843-878.

[35] Kalil, Ariel and James Kunz. 1999. "First Births Among Unmarried Adolescent Girls: Risk and Protective Factors" Social Work Research 23: 197-208.

[36] Kling, Jeffrey, Jeffrey Liebman, and Lawrence Katz. 2007. "Experimental Analysis of Neighborhood Effects." Econometrica, 75(1): 83-119.

[37] Kling, Jeffrey R., Jens Ludwig, and Lawrence F. Katz. 2005. "Neighborhood Effects on Crime for Female and Male Youth: Evidence from a Randomized Housing Mobility Experiment." Quarterly Journal of Economics, 120: 87-130.

[38] Lee, David S. 2009. "Training, Wages, and Sample Selection: Estimating Sharp Bounds on Treatment Effects." Review of Economic Studies, 76(3): 1071-1102.

[39] Liese, Angela D., Ralph B. D’Agostino, Richard F. Hamman, Patrick D. Kilgo, Jean M. Lawrence, Lenna L. Liu, Beth B. Loots, Barbara B. Linder, Santica S. Marcovina, Beatriz B. Rodriguez, Debra D. Standiford and Desmond E. Williams. 2006. "The Burden of Diabetes Mellitus Among U.S. Youth: Prevalence Estimates from the SEARCH for Diabetes in Youth Study." Pediatrics, 118(4): 1510-1580.

[40] Lopes, Antonio A. S. and Friedrich K. Port. 1995. "The Low Birth Weight Hypothesis as a Plausible Explanation for the Black/White Differences in Hypertension, Non-insulin-dependent Diabetes, and End-stage Renal Disease." American Journal of Kidney Disease, 25(2): 350-356.

[41] McGee, Rob and Sheila Williams. 2000. "Does Low Self-Esteem Predict Health-Compromising Behaviours Among Adolescents?" Journal of Adolescence 23: 569-582.

[42] Neal, Derek, and William Johnson. 1996. "The Role of Premarket Factors in Black-White Wage Differentials." Journal of Political Economy, 104: 869-895. 
[43] Paul, Charlotte, Julie Fitzjohn, Peter Herbison, and Nigel Dickson. 2000. "The Determinants of Sexual Intercourse Before Age 16." Journal of Adolescent Health 27(2): 136-147.

[44] Pettit, Becky, and Bruce Western. 2004. "Mass Imprisonment and the Life Course: Race and Class Inequality in U.S. Incarceration." American Sociological Review, 69: 151-169.

[45] Rodriguez-Planas, Nuria. 2012. "Longer-Term Impacts of Mentoring, Educational Services, and Learning Incentives: Evidence from a Randomized Trial in the United States." American Economic Journal: Applied Economics, 4(4): 121-39.

[46] Raymond, Margaret. 2009. "Multiple Choice: Charter School Performance in 16 States," Center for Research on Education Outcomes (CREDO) Report.

[47] Rosenberg, Morris. 1965. Society and the Adolescent Self-Image. Princeton, NJ: Princeton University Press.

[48] Rotter, Julian B. 1966. "Generalized Expectancies of Internal Versus External Control of Reinforcements." Psychological Monographs, 80(609).

[49] Sacerdote, Bruce. 2001. "Peer Effects with Random Assignment: Results for Dartmouth Roommates." Quarterly Journal of Economics, 116(2): 681-704.

[50] Sanbonmatsu, Lisa, Jeffrey R. Kling, Greg J. Duncan, and Jeanne Brooks-Gunn. 2006. "Neighborhoods and Academic Achievement: Results from the Moving to Opportunity Experiment." Journal of Human Resources, 41(4), 649-691.

[51] Sanbonmatsu, Lisa, Jens Ludwig, Lawrence F. Katz, Lisa A. Gennetian, Greg J. Duncan, Ronald C. Kessler, Emma Adam, Thomas W. McDade, and Stacy Tessler Lindau. 2011. "Moving to Opportunity for Fair Housing Demonstration Program - Final Impacts Evaluation." U.S. Department of Housing and Urban Development Report.

[52] Segal, Carmit. 2008. "Classroom Behavior." Journal of Human Resources, 43(4): 783-814.

[53] Stewart, Sherry H., Jordan B. Peterson, and Robert O. Pihl. 1995. "Anxiety Sensitivity and Self-Reported Alcohol Consumption Rates in University Women." Journal of Anxiety Disorders, 9(4): 283-292.

[54] Thernstrom, Abigail, and Stephan Thernstrom. 2004. "No Excuses: Closing the Racial Gap in Learning." Simon \& Schuster. 
[55] Tuttle, Christina Clark, Bing-ru Teh, Ira Nichols-Barrer, Brian P. Gill, and Philip Gleason. 2010. "Student Characteristics and Achievement in 22 KIPP Middle Schools: Final Report." Mathematica Policy Research, accessed at http://www.mathematica-mpr.com/ publications/PDFs/education/KIPP_fnlrpt.pdf

[56] Westfall, Peter H., and S. Stanley Young. 1993. Resampling-Based Multiple Testing: Examples and Methods for P-Value Adjustment. New York: Wiley.

[57] Whitman, David. 2008. Sweating the Small Stuff: Inner-City Schools and the New Paternalism. Washington, D.C.: Thomas B. Fordham Foundation \& Institute.

[58] Wilson, Willam. J. 1987. The Truly Disadvantaged: The Inner City, the Underclass, and Public Policy. Chicago: University of Chicago Press. 
Table 1

An Accounting of the Sample

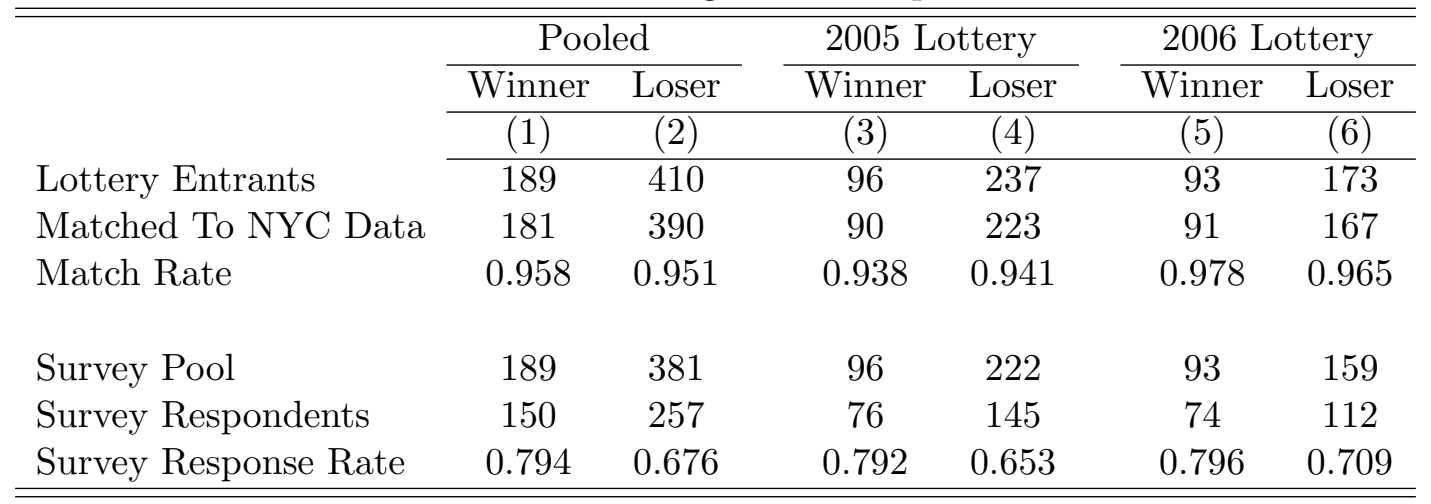

Notes: This table describes the match rate for Promise Academy lottery entrants to New York City administrative data and response rates for the in-person survey. The first row tabulates all students who entered the Promise Academy Middle School lottery in the Spring of 2005 or 2006, excluding students who were automatically admitted due to sibling preferences. The second row tabulates students whom we are able to match to New York City administrative data using the matching algorithm described in the Web Appendix. The third row displays the percentage of students who are succesfully matched. Our survey pool includes all lottery entrants except for the group of randomly selected lottery losers that were used to test and callibrate the survey instrument during the Fall of 2011, along with any records that were discovered to be mistaken matches and/or duplicates during the survey process. The fifth row tabulates all students who completed our survey, and the sixth reports the percentage of the survey pool who responded. 


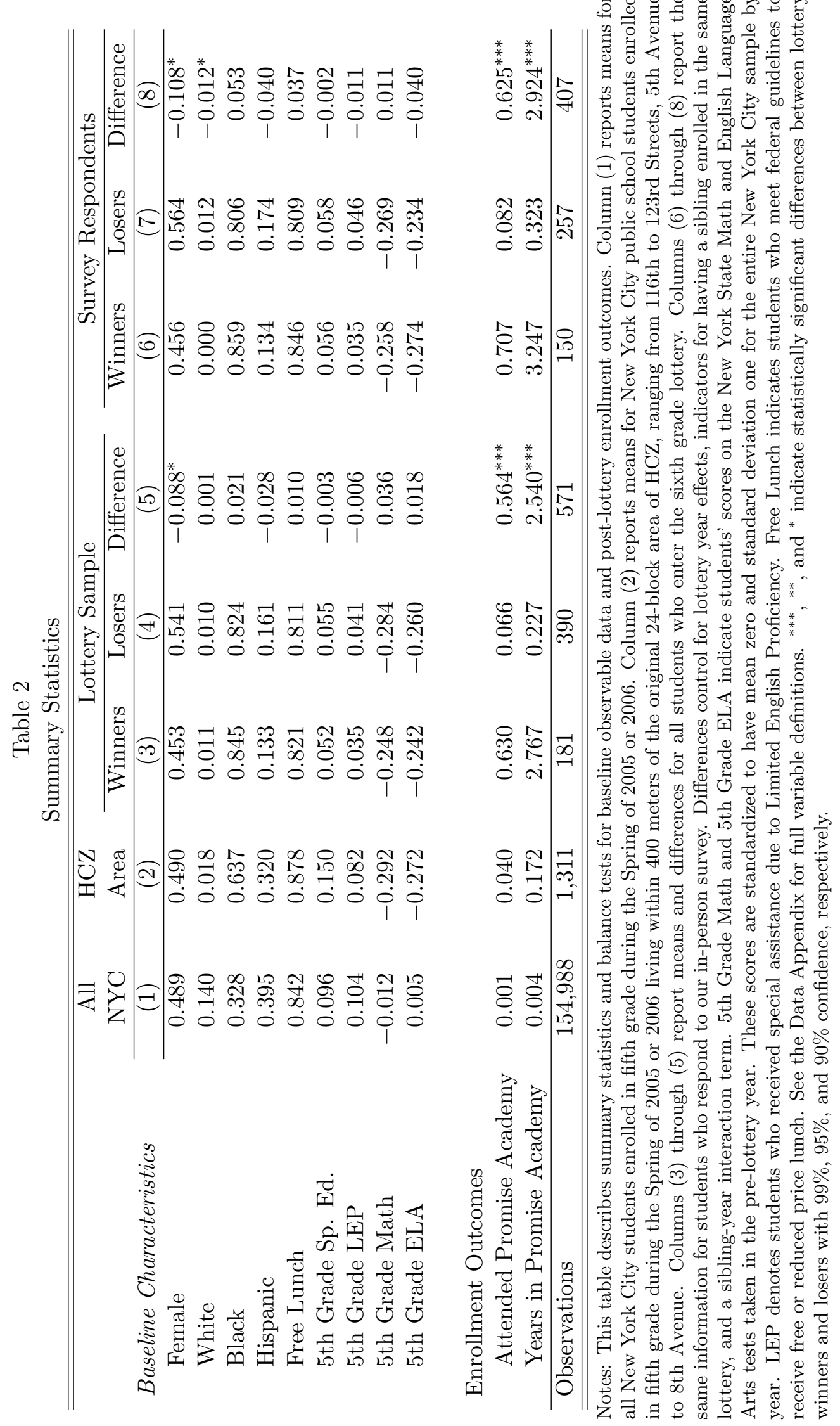


Table 3

Youth Characteristics and Survey Response

\begin{tabular}{|c|c|c|c|c|}
\hline & $\begin{array}{l}\text { All Lottery } \\
\text { Entrants }\end{array}$ & $\begin{array}{c}\text { Lottery } \\
\text { Winners }\end{array}$ & $\begin{array}{l}\text { Lottery } \\
\text { Losers }\end{array}$ & Difference \\
\hline Panel A. Characteristics & $(1)$ & $(2)$ & $(3)$ & $(4)$ \\
\hline Female & $\begin{array}{c}0.057 \\
(0.039)\end{array}$ & $\begin{array}{r}-0.022 \\
(0.064)\end{array}$ & $\begin{array}{c}0.091^{*} \\
(0.050)\end{array}$ & $\begin{array}{c}-0.112 \\
(0.081)\end{array}$ \\
\hline Black & $\begin{array}{r}-0.005 \\
(0.049)\end{array}$ & $\begin{array}{c}0.096 \\
(0.091)\end{array}$ & $\begin{array}{r}-0.045 \\
(0.060)\end{array}$ & $\begin{array}{c}0.139 \\
(0.108)\end{array}$ \\
\hline Free Lunch & $\begin{array}{c}0.026 \\
(0.051)\end{array}$ & $\begin{array}{c}0.114 \\
(0.088)\end{array}$ & $\begin{array}{c}-0.029 \\
(0.064)\end{array}$ & $\begin{array}{c}0.141 \\
(0.108)\end{array}$ \\
\hline 5th Grade Sp. Ed. & $\begin{array}{c}0.016 \\
(0.092)\end{array}$ & $\begin{array}{c}0.047 \\
(0.122)\end{array}$ & $\begin{array}{c}0.022 \\
(0.117)\end{array}$ & $\begin{array}{c}0.027 \\
(0.168)\end{array}$ \\
\hline 5th Grade LEP & $\begin{array}{c}0.064 \\
(0.120)\end{array}$ & $\begin{array}{c}-0.365 \\
(0.263)\end{array}$ & $\begin{array}{c}0.141 \\
(0.124)\end{array}$ & $\begin{array}{r}-0.508^{*} \\
(0.288)\end{array}$ \\
\hline 5th Grade Math & $\begin{array}{r}-0.013 \\
(0.035)\end{array}$ & $\begin{array}{c}0.015 \\
(0.058)\end{array}$ & $\begin{array}{r}-0.025 \\
(0.046)\end{array}$ & $\begin{array}{c}0.040 \\
(0.073)\end{array}$ \\
\hline 5th Grade ELA & $\begin{array}{c}0.007 \\
(0.033)\end{array}$ & $\begin{array}{c}-0.051 \\
(0.051)\end{array}$ & $\begin{array}{c}0.043 \\
(0.044)\end{array}$ & $\begin{array}{r}-0.095 \\
(0.067)\end{array}$ \\
\hline Missing 5th Grade Math & $\begin{array}{r}-0.073 \\
(0.160)\end{array}$ & $\begin{array}{c}-0.383 \\
(0.273)\end{array}$ & $\begin{array}{r}-0.029 \\
(0.190)\end{array}$ & $\begin{array}{c}-0.352 \\
(0.330)\end{array}$ \\
\hline Missing 5th Grade ELA & $\begin{array}{c}0.023 \\
(0.135)\end{array}$ & $\begin{array}{c}0.529^{* *} \\
(0.262)\end{array}$ & $\begin{array}{c}-0.093 \\
(0.161)\end{array}$ & $\begin{array}{c}0.624^{* *} \\
(0.305)\end{array}$ \\
\hline Missing Demographics & $\begin{array}{c}0.004 \\
(0.139) \\
541\end{array}$ & $\begin{array}{c}-0.114 \\
(0.187) \\
181\end{array}$ & $\begin{array}{c}0.027 \\
(0.173) \\
360\end{array}$ & $\begin{array}{c}-0.143 \\
(0.253) \\
541\end{array}$ \\
\hline \multicolumn{5}{|l|}{ Panel B. Observed Outcomes } \\
\hline Eight Grade Math & $\begin{array}{c}0.049^{* *} \\
(0.023) \\
452\end{array}$ & $\begin{array}{c}0.034 \\
(0.035) \\
157\end{array}$ & $\begin{array}{c}0.036 \\
(0.032) \\
295\end{array}$ & $\begin{array}{c}-0.002 \\
(0.047) \\
452\end{array}$ \\
\hline Eight Grade ELA & $\begin{array}{r}-0.007 \\
(0.030)\end{array}$ & $\begin{array}{r}-0.038 \\
(0.037)\end{array}$ & $\begin{array}{c}0.007 \\
(0.043)\end{array}$ & $\begin{array}{r}-0.045 \\
(0.056)\end{array}$ \\
\hline College Enrollment & $\begin{array}{l}457 \\
0.207^{* * *} \\
(0.048) \\
298\end{array}$ & $\begin{array}{c}160 \\
0.204^{* * *} \\
(0.074) \\
90\end{array}$ & $\begin{array}{c}297 \\
0.189^{* * *} \\
(0.063) \\
208\end{array}$ & $\begin{array}{c}457 \\
0.016 \\
(0.097) \\
298\end{array}$ \\
\hline p-value from Joint F-test Panel $A$ & 0.867 & 0.241 & 0.667 & 0.163 \\
\hline p-value from Joint F-test Panel $B$ & 0.000 & 0.006 & 0.016 & 0.808 \\
\hline
\end{tabular}


Notes: This table reports the results of OLS regressions of an indicator for survey response on baseline characteristics and observed outcomes. The sample for eighth grade scores include lottery entrants not in the pre-test group who are matched to the NYC administrative data. The sample for college enrollment includes all non-pre-test 2005 lottery entrants. Woodcock-Johnson scores are restricted to the survey sample, ever pregnant is restricted to females in the survey sample, and incarcerated is restricted to males whom we successfully contacted. All regressions control for lottery-year indicators, indicators for having a sibling enrolled in the same lottery, and a sibling-year interaction term. Regressions in Panels B also control for the baseline demographic variables summarized in Table 2 and a quadratic of 4 th and 5th grade math and ELA test scores. The final two rows report the p-value from a joint F-test of the null hypothesis that all coefficients in each Panel equal zero, estimated via seemingly unrelated regression in Panel B. Heteroskedasticity-robust standard errors are reported in parenthesis. The number of observations is reported below the standard errors in Panel B. ${ }^{* * *},{ }^{* *}$, and ${ }^{*}$ indicate statistical significance with $99 \%, 95 \%$, and $90 \%$ confidence, respectively. 
Table 4

The Impact of Attending the Promise Academy on Human Capital, Risky Behaviors, and Health

\begin{tabular}{|c|c|c|c|}
\hline \multirow{4}{*}{$\begin{array}{l}\text { Panel A. Human Capital } \\
\text { Woodcock Johnson Math }\end{array}$} & $\mathrm{CM}$ & ITT & LATE \\
\hline & (1) & $(2)$ & $(3)$ \\
\hline & 0.000 & $0.283^{* * *}$ & $0.439^{* * *}$ \\
\hline & $(1.000)$ & $(0.083)$ & $(0.121)$ \\
\hline \multirow{4}{*}{ Woodcock Johnson Reading } & 243 & 386 & 386 \\
\hline & 0.000 & 0.119 & 0.185 \\
\hline & $(1.000)$ & $(0.083)$ & $(0.123)$ \\
\hline & 243 & 386 & 386 \\
\hline \multirow[t]{3}{*}{ Regents Passed } & 3.571 & $1.115^{* * *}$ & $1.788^{* * *}$ \\
\hline & $(2.610)$ & $(0.277)$ & $(0.401)$ \\
\hline & 308 & 453 & 453 \\
\hline \multirow[t]{3}{*}{ Regents Test Scores } & -0.362 & $0.270^{* * *}$ & $0.423^{* * *}$ \\
\hline & $(0.844)$ & $(0.089)$ & $(0.130)$ \\
\hline & 285 & 423 & 423 \\
\hline \multirow[t]{3}{*}{ College Enrollment } & 0.288 & $0.141^{* *}$ & $0.242^{* *}$ \\
\hline & $(0.454)$ & $(0.061)$ & $(0.097)$ \\
\hline & 236 & 313 & 313 \\
\hline \multirow[t]{3}{*}{ Human Capital Index } & -0.055 & $0.267^{* * *}$ & $0.437^{* * *}$ \\
\hline & $(0.841)$ & $(0.070)$ & $(0.106)$ \\
\hline & 391 & 552 & 552 \\
\hline \multicolumn{4}{|l|}{ Panel B. Risky Behaviors } \\
\hline \multirow[t]{3}{*}{ Ever Pregnant (Female) } & 0.170 & $-0.121^{* * *}$ & $-0.183^{* * *}$ \\
\hline & $(0.377)$ & $(0.046)$ & $(0.067)$ \\
\hline & 141 & 205 & 205 \\
\hline \multirow[t]{3}{*}{ Incarcerated (Male) } & 0.041 & $-0.043^{* *}$ & $-0.075^{* *}$ \\
\hline & $(0.200)$ & $(0.018)$ & $(0.030)$ \\
\hline & 145 & 234 & 234 \\
\hline \multirow[t]{3}{*}{ Drug/Alcohol Index } & -0.001 & -0.016 & -0.025 \\
\hline & $(0.692)$ & $(0.067)$ & $(0.103)$ \\
\hline & 256 & 406 & 406 \\
\hline \multirow[t]{3}{*}{ Criminal Behavior Index } & 0.000 & -0.004 & -0.007 \\
\hline & $(0.618)$ & $(0.065)$ & $(0.101)$ \\
\hline & 257 & 407 & 407 \\
\hline \multirow[t]{3}{*}{ Risky Behavior Index } & 0.053 & $-0.135^{*}$ & $-0.223^{*}$ \\
\hline & $(0.896)$ & $(0.072)$ & $(0.117)$ \\
\hline & 289 & 445 & 445 \\
\hline \multicolumn{4}{|l|}{ Panel C. Health } \\
\hline \multirow[t]{3}{*}{ Nutrition Index } & 0.000 & $0.108^{*}$ & $0.173^{*}$ \\
\hline & $(0.572)$ & $(0.061)$ & $(0.095)$ \\
\hline & 257 & 407 & 407 \\
\hline \multirow[t]{3}{*}{ Mental Health } & 0.000 & -0.034 & -0.054 \\
\hline & $(1.000)$ & $(0.103)$ & $(0.161)$ \\
\hline & 254 & 403 & 403 \\
\hline Physical Health Index & 0.000 & -0.050 & -0.079 \\
\hline
\end{tabular}


Health Behavior Index

Health Index

Notes: This table reports estimates of the effect of attending the Promise Academy. Column (1) reports the mean and standard deviation of each variable for the control group. Column (2) reports ITT estimates of the impact of winning the admissions lottery. Column (3) reports LATE estimates of the impact of ever attending the Promise Academy using a winning lottery number as an instrument. All regressions control for the baseline demographic variables summarized in Table 2, a quadratic of 4th and 5th grade math and ELA test scores, lottery-year indicators, indicators having a sibling enrolled in the same lottery, and a sibling-year interaction term. The sample for Regents results includes all lottery entrants who enroll at a NYC high school for at least one year. College enrollment includes all 2005 lottery entrants. Ever pregnant is restricted to female entrants in the survey sample, and incarcerated is restricted to male entrants whom we successfully contacted. All other outcomes are restricted to youth in the survey sample who answered the indicated question. Each index variable is restricted to youth with at least one non-missing outcome in that domain. Woodcock-Johnson scores come from the Brief Battery described in Web Appendix B. Regents passed equals the number of Regents exams with scores over 65 out of 100 . Regents test scores is the mean of the standardized score on the Integrated Algebra, Living Enviroment, and World History exams, and includes all youth with at least one non-missing score. Incarceration is an indicator for being incarcerated during the survey period. The drug/alcohol index is the average of standardized indicators for having used marijuana in the past 30 days, having consumed alcohol in the past 30 days, and having used hard drugs in the past year. The criminal behavior index is the average of standardized indicators for having ever destroyed property, having ever stolen an item worth less than $\$ 50$, having ever stolen an item worth more than $\$ 50$, having ever committed any other type of property crime, having ever been in serious fight, having ever carried a handgun, and having ever been a gang member. The nutrition index is equal to the average of the standardized fruit and vegetable consumption, negated soft drink consumption, negated sugary snacks consumption, and negated fast food consumption. The mental health index is the standardized K6 Anxiety Scale, defined as the sum of a student's responses on a five point Likert Scale to six statements assessing one's mental state. The physical health index is the average of (negated) standardized indicators for reporting poor health, chronic health problems, having had an asthma attack in the past year, and having a BMI in the 95th percentile or above. The health behavior index is equal to the average of standardized indicators having had a physical examination in past year, reporting vigorous physical activity, reporting moderate physical activity, and having had a dental examination in past year. The last row of each Panel is a summary index equal to the average of the standardized value of each of the preceding variables. Each standardized survey outcome is renormed using the mean and standard deviation of the control group. Administrative outcomes are renormed using the mean and standard deviation of the entire NYC sample. Web Appendix B contains additional details on each variable. Heteroskedasticity-robust standard errors are reported in parenthesis. The number of observations is reported below the standard error. ${ }^{* * *},{ }^{* *}$, and ${ }^{*}$ indicate statistical significance with $99 \%, 95 \%$, and $90 \%$ confidence, respectively. 
Table 5

Attrition and Bounding

\begin{tabular}{|c|c|c|c|c|c|c|}
\hline & $\begin{array}{c}\text { Admin } \\
\text { ITT }\end{array}$ & $\begin{array}{c}\text { Survey } \\
\text { ITT }\end{array}$ & $\begin{array}{c}\text { Lee } \\
\text { Bound }\end{array}$ & $\begin{array}{c}\text { p-value } \\
(2)=(3)\end{array}$ & Imputed & $\begin{array}{c}\text { p-value } \\
(2)=(5)\end{array}$ \\
\hline \multirow{4}{*}{$\begin{array}{l}\text { Panel A1. Human Capital (Admin.) } \\
\text { Eight Grade Math }\end{array}$} & (1) & $(2)$ & $(3)$ & & (5) & \\
\hline & $0.446^{* * *}$ & $0.466^{* * *}$ & $0.233^{* * *}$ & & $0.343^{* * *}$ & \\
\hline & 0.077 & $(0.081)$ & $(0.079)$ & 0.040 & $(0.065)$ & 0.237 \\
\hline & 472 & 361 & 335 & & 547 & \\
\hline \multirow[t]{3}{*}{ Eight Grade ELA } & $0.156^{* * *}$ & $0.132^{* *}$ & -0.040 & & $0.108^{* * *}$ & \\
\hline & 0.057 & $(0.055)$ & $(0.049)$ & 0.021 & $(0.041)$ & 0.735 \\
\hline & 477 & 365 & 337 & & 547 & \\
\hline \multirow[t]{3}{*}{ Regents Passed } & $1.115^{* * *}$ & $1.289^{* * *}$ & $0.487^{*}$ & & $0.977^{* * *}$ & \\
\hline & 0.277 & $(0.298)$ & $(0.290)$ & 0.054 & $(0.267)$ & 0.435 \\
\hline & 453 & 348 & 323 & & 547 & \\
\hline \multirow[t]{3}{*}{ Regents Test Scores } & $0.270^{* * *}$ & $0.267^{* * *}$ & 0.033 & & $0.221^{* * *}$ & \\
\hline & 0.089 & $(0.097)$ & $(0.103)$ & 0.098 & $(0.073)$ & 0.705 \\
\hline & 433 & 334 & 309 & & 547 & \\
\hline \multirow[t]{3}{*}{ College Enrollment } & $0.141^{* *}$ & $0.155^{* *}$ & 0.010 & & $0.149^{* *}$ & \\
\hline & 0.061 & $(0.072)$ & $(0.071)$ & 0.149 & $(0.063)$ & 0.947 \\
\hline & 313 & 220 & 206 & & 299 & \\
\hline \multirow[t]{3}{*}{ Human Capital Index } & $0.267^{* * *}$ & $0.279^{* * *}$ & 0.098 & & $0.230^{* * *}$ & \\
\hline & 0.070 & $(0.074)$ & $(0.069)$ & 0.075 & $(0.061)$ & 0.610 \\
\hline & 544 & 403 & 382 & & 547 & \\
\hline \multicolumn{7}{|l|}{ Panel A2. Human Capital (Survey) } \\
\hline \multirow[t]{3}{*}{ Woodcock Johnson Math } & & $0.283^{* * *}$ & 0.053 & & $0.207^{* * *}$ & \\
\hline & - & $(0.083)$ & $(0.073)$ & 0.038 & $(0.070)$ & 0.480 \\
\hline & & 386 & 364 & & 547 & \\
\hline \multirow[t]{3}{*}{ Woodcock Johnson Reading } & & 0.119 & -0.107 & & 0.089 & \\
\hline & - & $(0.083)$ & $(0.074)$ & 0.042 & $(0.069)$ & 0.776 \\
\hline & & 386 & 364 & & 547 & \\
\hline \multicolumn{7}{|l|}{ Panel B. Risky Behaviors } \\
\hline \multirow[t]{3}{*}{ Ever Pregnant (Female) } & & $-0.121^{* * *}$ & $-0.102^{* *}$ & & $-0.097^{* * *}$ & \\
\hline & - & $(0.046)$ & $(0.046)$ & 0.776 & $(0.036)$ & 0.684 \\
\hline & & 205 & 202 & & 272 & \\
\hline \multirow[t]{3}{*}{ Incarcerated (Male) } & & $-0.043^{* *}$ & & & $-0.033^{*}$ & \\
\hline & - & $(0.018)$ & - & - & $(0.018)$ & 0.706 \\
\hline & & 234 & & & 271 & \\
\hline \multirow[t]{3}{*}{ Drug/Alcohol Index } & & -0.016 & 0.108 & & -0.008 & \\
\hline & - & $(0.067)$ & $(0.069)$ & 0.198 & $(0.050)$ & 0.929 \\
\hline & & 406 & 384 & & 547 & \\
\hline \multirow[t]{3}{*}{ Criminal Behavior Index } & & -0.004 & 0.085 & & -0.010 & \\
\hline & - & $(0.065)$ & $(0.068)$ & 0.342 & $(0.049)$ & 0.948 \\
\hline & & 407 & 386 & & 547 & \\
\hline \multirow[t]{3}{*}{ Risky Behavior Index } & & -0.043 & 0.056 & & -0.037 & \\
\hline & - & $(0.062)$ & $(0.065)$ & 0.269 & $(0.046)$ & 0.936 \\
\hline & & 407 & 386 & & 547 & \\
\hline \multicolumn{7}{|l|}{ Panel C. Health } \\
\hline \multirow[t]{3}{*}{ Nutrition Index } & & $0.108^{*}$ & -0.021 & & $0.081^{*}$ & \\
\hline & - & $(0.061)$ & $(0.058)$ & 0.125 & $(0.047)$ & 0.721 \\
\hline & & 407 & 386 & & 547 & \\
\hline \multirow[t]{3}{*}{ Mental Health } & & -0.034 & $-0.230^{* *}$ & & -0.038 & \\
\hline & - & $(0.103)$ & $(0.103)$ & 0.177 & $(0.077)$ & 0.971 \\
\hline & & 403 & 382 & & 547 & \\
\hline Physical Health Index & & -0.050 & $-0.162^{* *}$ & & -0.033 & \\
\hline
\end{tabular}




\begin{tabular}{|c|c|c|c|c|c|c|}
\hline & - & $(0.063)$ & $(0.063)$ & 0.209 & $(0.047)$ & 0.829 \\
\hline & & 407 & 386 & & 547 & \\
\hline Health Behavior Index & & 0.031 & $-0.085^{*}$ & & 0.033 & \\
\hline & - & $(0.052)$ & $(0.050)$ & 0.111 & $(0.040)$ & 0.977 \\
\hline & & 407 & 386 & & 547 & \\
\hline Health Index & & 0.032 & $-0.090^{*}$ & & 0.028 & \\
\hline & - & $(0.057)$ & $(0.054)$ & 0.119 & $(0.043)$ & 0.951 \\
\hline & & 407 & 386 & & 547 & \\
\hline
\end{tabular}

Notes: This table reports ITT estimates accounting for survey attrition. Column (1) reports ITT estimates in the administrative sample not subject to attrition bias. Column (2) reports ITT estimates in the sample of survey respondents. Column (3) reports Lee (2009) bounds by dropping lottery winners with the best residual outcomes until there is an equal survey response rate between lottery winners and lottery losers. Column (4) reports the p-value from a test that the coefficients in Columns (2) and (3) are equal. Column (5) reports results imputing outcomes for all survey non-respondents using all baseline characteristics reported in Table 2 and the five administrative outcomes reported in Panel A. Column (6) reports the p-value from a test that the coefficients in Columns (2) and (5) are equal. All regressions follow the specification and sample restrictions from Table 4. Heteroskedasticity-robust standard errors are reported in parenthesis. The number of observations is reported below the standard error. ${ }^{* * *},{ }^{* *}$, and ${ }^{*}$ indicate statistical significance with $99 \%, 95 \%$, and $90 \%$ confidence, respectively. 
Table 6

The Impact of Attending the Promise Academy Inside and Outside the Zone

\begin{tabular}{cccc}
\hline \hline & Inside & Outside & \\
& Zone & Zone & p-value \\
\cline { 2 - 4 } & $(1)$ & $(2)$ & $(3)$ \\
\cline { 2 - 4 } Human Capital Index & $0.281^{* *}$ & $0.268^{* * *}$ & \\
& $(0.124)$ & $(0.077)$ & 0.918 \\
& 147 & 361 & \\
Risky Behavior Index & -0.127 & $-0.135^{*}$ & \\
& $(0.103)$ & $(0.077)$ & 0.932 \\
Health Index & 122 & 315 & \\
& 0.045 & 0.034 & \\
& $(0.094)$ & $(0.062)$ & 0.907 \\
\hline \hline
\end{tabular}

Notes: This table reports ITT estimates for youth with baseline addresses inside and outside of the Harlem Children's Zone. Column (1) presents ITT estimates for youth living within 400 meters of the original 24-block Zone. Column (2) presents ITT estimates for youth living outside 400 meters of the original 24-block Zone, and Column (3) reports a p-value of a test that the two coefficients are equal. Students with no baseline address information are dropped. All specifications and variable definitions are identical to those in Table 4.Heteroskedasticity-robust standard errors are reported in parenthesis. The number of observations is reported below the standard error. ${ }^{* * *},{ }^{* *}$, and ${ }^{*}$ indicate statistical significance with $99 \%, 95 \%$, and $90 \%$ confidence, respectively. 
Table 7

Impact of Attending a High-Quality Charter

High School on College Quality

\begin{tabular}{cccc}
\hline \hline & CM & ITT & LATE \\
\cline { 2 - 4 } & $(1)$ & $(2)$ & $(3)$ \\
\cline { 2 - 4 } College Enrollment & 0.530 & $0.049^{* * *}$ & $0.088^{* * *}$ \\
& $(0.499)$ & $(0.014)$ & $(0.025)$ \\
Two Year College & 4937 & 6826 & 6826 \\
& 0.266 & -0.002 & -0.004 \\
Four Year College & $0.442)$ & $(0.013)$ & $(0.024)$ \\
& 4937 & 6826 & 6826 \\
\multirow{2}{*}{ 1000+ SAT College } & 0.378 & $0.063^{* * *}$ & $0.114^{* * *}$ \\
& $0.485)$ & $(0.014)$ & $(0.026)$ \\
& $(0.4238$ & 6826 & 6826 \\
& 4937 & $0.063^{* * *}$ & $0.114^{* * *}$ \\
& $0.013)$ & $(0.024)$ \\
\hline \hline
\end{tabular}

Notes: This table reports estimates of the effect of attending the Denver School of Science and Technology, Match, Noble, and Summit Preparatory charter high schools on college enrollment. Column (1) reports the mean and standard deviation of each variable for the control group. Column (2) reports ITT estimates of the impact of winning the admissions lottery. Column (3) reports LATE estimates of the impact of ever attending the school using a winning lottery number as an instrument. All regressions control for gender, lottery-year indicators, indicators having a sibling enrolled in the same lottery, and a sibling-year interaction term. Heteroskedasticity-robust standard errors are reported in parenthesis. The number of observations is reported below the standard error. ***, **, and * indicate statistical significance with $99 \%, 95 \%$, and $90 \%$ confidence, respectively. See text for additional details. 
Appendix Table 1

Characteristics of Charter Schools

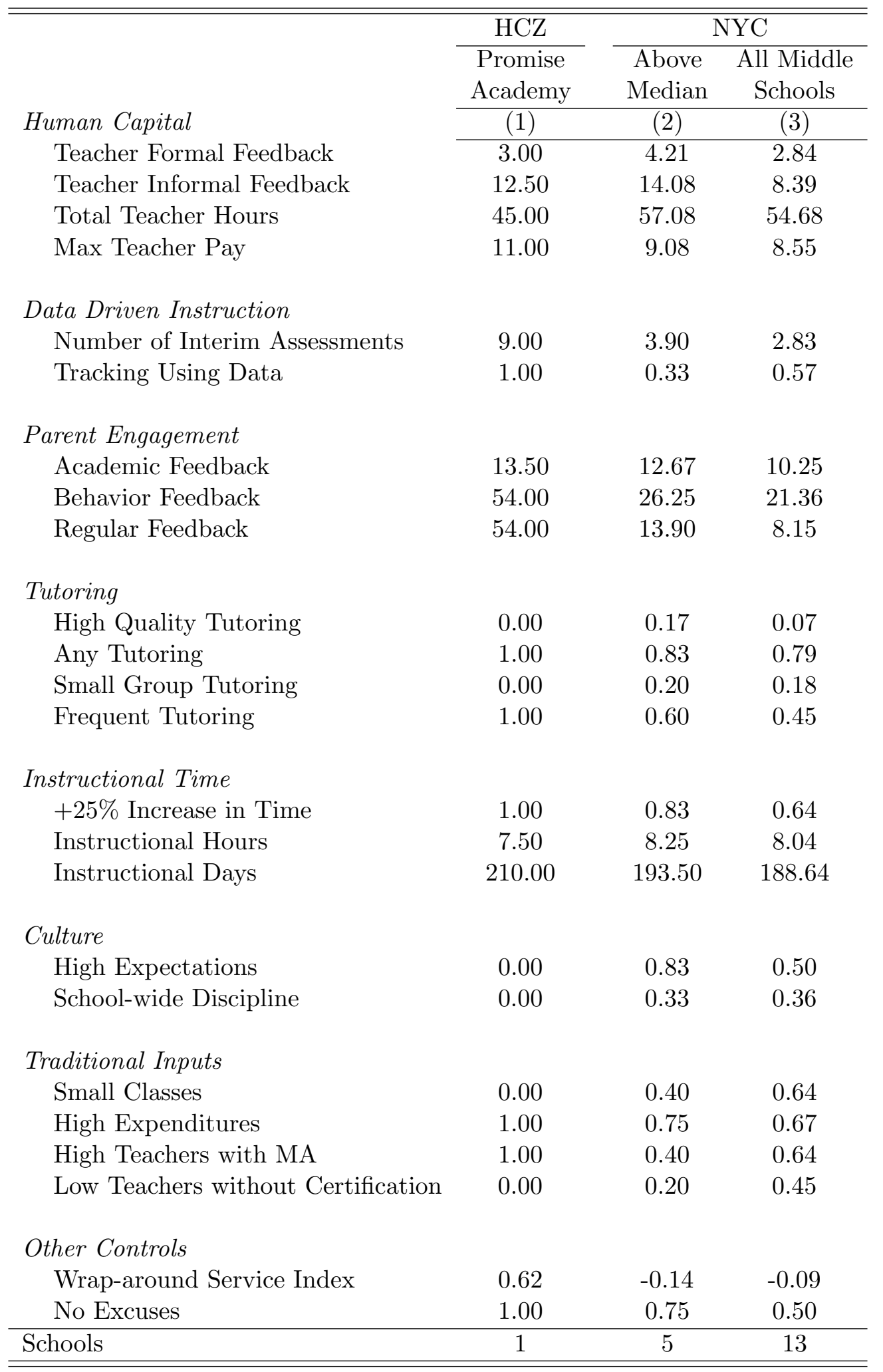


Notes: This table reports results from a survey of 35 New York City charter schools administered by Dobbie and Fryer (2011b). Column (1) reports the mean of each variable for the Promise Academy Middle School. Column (2) includes all schools with entry in middle school grades (5th - 8th) whose average treatment effects on Math and ELA scores are above the median in the sample. Column (3) includes all Middle Schools in the sample with a tested grade in 2010-2011. See Dobbie and Fryer (2011b) for variable definitions and codings. 
Appendix Table 2

The Impact of Attending the

Promise Academy on College Quality

\begin{tabular}{cccc}
\hline \hline & CM & ITT & LATE \\
\cline { 2 - 4 } & $(1)$ & $(2)$ & $(3)$ \\
\cline { 2 - 4 } College Enrollment & 0.288 & $0.141^{* *}$ & $0.242^{* *}$ \\
& $(0.454)$ & $(0.061)$ & $(0.097)$ \\
Two Year College & 236 & 313 & 313 \\
& 0.081 & $-0.072^{* * *}$ & $-0.124^{* * *}$ \\
Four Year College & $0.273)$ & $(0.023)$ & $(0.039)$ \\
& 236 & 313 & 313 \\
\multirow{2}{*}{ 1000+ SAT College } & 0.208 & $0.213^{* * *}$ & $0.366^{* * *}$ \\
& $0.406)$ & $(0.059)$ & $(0.093)$ \\
& 236 & 313 & 313 \\
& $(0.279)$ & 0.045 & 0.078 \\
& 236 & 313 & 313 \\
\hline \hline
\end{tabular}

Notes: This table reports estimates of the effect of attending the Promise Academy on college quality. Column (1) reports the mean of each variable for the control group. Column (2) reports ITT estimates of the impact of winning the admissions lottery. Column (3) reports LATE estimates of the impact of ever attending the Promise Academy using a winning lottery number as an instrument. The sample is restricted to 2005 lottery entrants. All regressions control for the baseline demographic variables summarized in Table 2, a quadratic of 4th and 5th grade math and ELA test scores, lottery-year indicators, indicators having a sibling enrolled in the same lottery, and a sibling-year interaction term. Colleges that we cannot match to SAT or ACT data are coded as zero. Heteroskedasticity-robust standard errors are reported in parenthesis. The number of observations is reported below the standard error. ${ }^{* * *}$, **, and * indicate statistical significance with $99 \%, 95 \%$, and $90 \%$ confidence, respectively. 
Appendix Table 3

Main Estimates with Familywise-Error-Rate-Controlled p-values

\begin{tabular}{cccc}
\hline \hline & $\begin{array}{c}\text { ITT } \\
\text { Estimate }\end{array}$ & $\begin{array}{c}\text { Uncorrected } \\
\text { p-value }\end{array}$ & $\begin{array}{c}\text { Corrected } \\
\text { p-value }\end{array}$ \\
\cline { 2 - 4 } & $(1)$ & $(2)$ & $(3)$ \\
\cline { 2 - 4 } Human Capital Index & 0.267 & 0.000 & 0.000 \\
& $(0.070)$ & & \\
Risky Behavior Index & $\begin{array}{c}0.135 \\
\text { (0.072) }\end{array}$ & 0.063 & 0.123 \\
Health Index & 0.032 & 0.573 & 0.573 \\
& $(0.057)$ & & \\
\hline \hline
\end{tabular}

Notes: This table reports ITT estimates correcting for multiple-hypothesis testing. Column (1) reports ITT estimates following the specification described in Table 4. Column (2) reports the unadjusted p-value. Column (3) reports the p-value correcting for the Familywise Error Rate for the three outcomes. Web Appendix E contains additional information on the algorithm used. Standard errors reported in parenthesis are robust to arbitrary heteroskedasticity. The number of observations is reported below the standard error. 
Appendix Table 4

The Impact of Attending the Promise Academy Inside and Outside the Zone

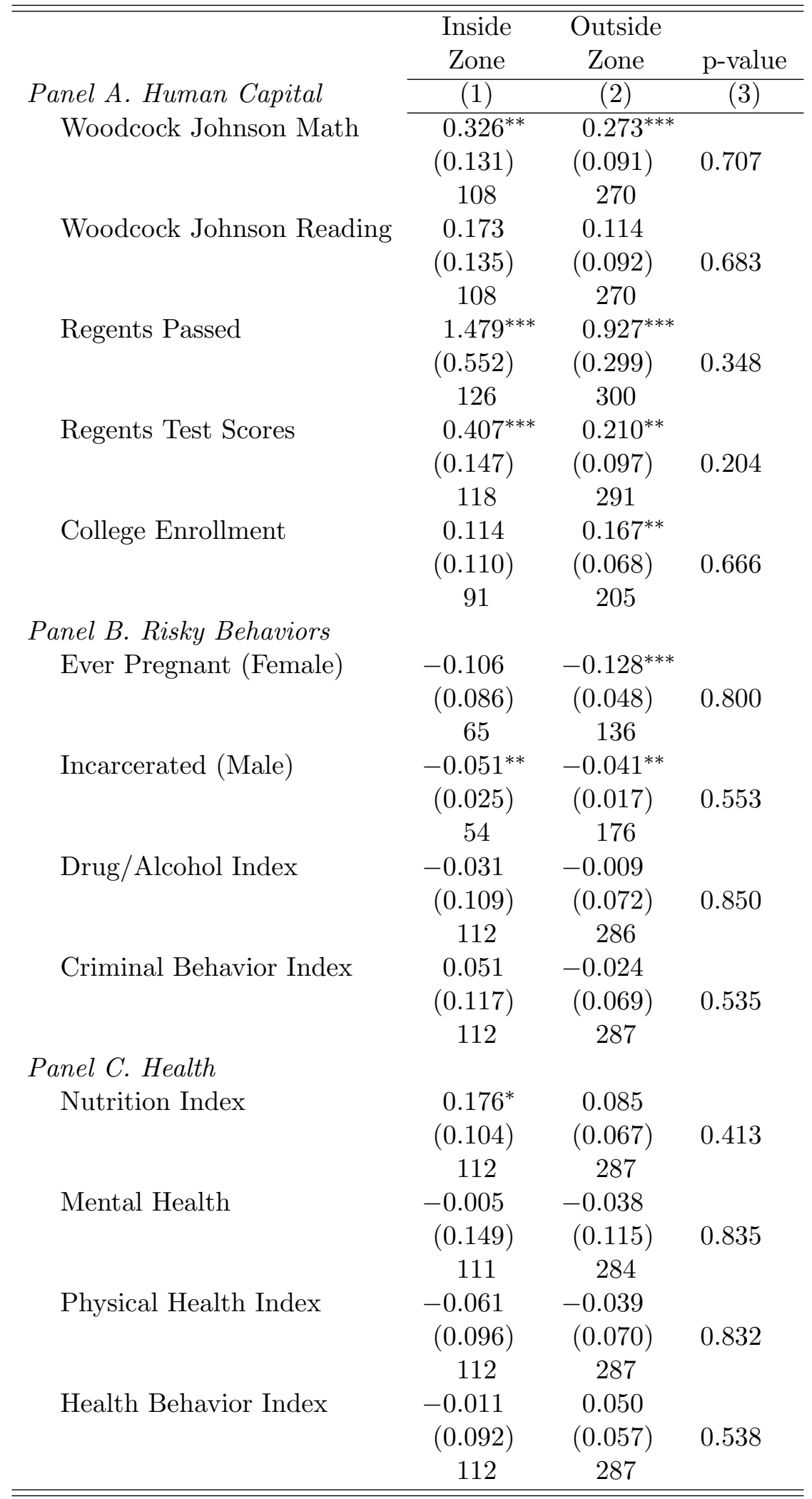


Notes: This table reports ITT estimates for youth with baseline addresses inside and outside of the Harlem Children's Zone. Column (1) presents ITT estimates for youth living within 400 meters of the original 24-block Zone. Column (2) presents ITT estimates for youth living outside 400 meters of the original 24-block Zone, and Column (3) reports a p-value of a test that the two coefficients are equal. All specifications and variable definitions are identical to those in Table 4. Heteroskedasticity-robust standard errors are reported in parenthesis. The number of observations is reported below the standard error. ${ }^{* * *},{ }^{* *}$, and ${ }^{*}$ indicate statistical significance with $99 \%, 95 \%$, and $90 \%$ confidence, respectively. 
Appendix Table 5

Comparison of Promise Academy and MTO Effects

\begin{tabular}{|c|c|c|c|c|}
\hline & \multicolumn{2}{|c|}{ Female } & \multicolumn{2}{|c|}{ Male } \\
\hline & MTO & $\mathrm{HCZ}$ & MTO & $\mathrm{HCZ}$ \\
\hline Panel A. Woodcock Johnson & $(1)$ & $(2)$ & $(3)$ & $(4)$ \\
\hline \multirow[t]{2}{*}{ Woodcock Johnson Math } & 0.119 & $0.251^{*}$ & -0.095 & $0.310^{* * *}$ \\
\hline & $(0.095)$ & $(0.137)$ & $(0.097)$ & $(0.108)$ \\
\hline \multirow[t]{2}{*}{ Woodcock Johnson Reading } & 0.093 & 0.162 & -0.087 & 0.096 \\
\hline & $(0.084)$ & $(0.133)$ & $(0.096)$ & $(0.113)$ \\
\hline \multicolumn{5}{|l|}{ Panel B. Health } \\
\hline \multirow[t]{2}{*}{ Self Reported Health Poor/Fair } & -0.008 & -0.019 & 0.033 & 0.030 \\
\hline & $(0.029)$ & $(0.045)$ & $(0.019)$ & $(0.034)$ \\
\hline \multirow[t]{2}{*}{ Had Asthma Attack in Last Year } & 0.002 & 0.075 & 0.016 & -0.003 \\
\hline & $(0.037)$ & $(0.071)$ & $(0.032)$ & $(0.051)$ \\
\hline \multirow[t]{2}{*}{ BMI $>$ 95th Percentile } & -0.009 & -0.037 & 0.026 & 0.018 \\
\hline & $(0.034)$ & $(0.060)$ & $(0.037)$ & $(0.061)$ \\
\hline \multirow[t]{2}{*}{ Mental Health } & $0.289^{*}$ & -0.088 & -0.095 & 0.056 \\
\hline & $(0.094)$ & $(0.169)$ & $(0.085)$ & $(0.138)$ \\
\hline \multicolumn{5}{|l|}{ Panel C. Risky Behaviors } \\
\hline \multirow[t]{2}{*}{ Drank Alcohol in Last 30 Days } & -0.060 & -0.062 & 0.063 & 0.017 \\
\hline & $(0.037)$ & $(0.067)$ & $(0.033)$ & $(0.071)$ \\
\hline \multirow[t]{2}{*}{ Smoked Marijuana in Last 30 Days } & $-0.065^{*}$ & -0.019 & 0.051 & 0.063 \\
\hline & $(0.029)$ & $(0.067)$ & $(0.030)$ & $(0.068)$ \\
\hline \multirow[t]{2}{*}{ Smoked Cigarette in Last 30 Days } & -0.054 & 0.025 & $0.103^{*}$ & 0.023 \\
\hline & $(0.033)$ & $(0.045)$ & $(0.032)$ & $(0.038)$ \\
\hline \multirow[t]{2}{*}{ Ever Been Pregnant or Caused Pregnancy } & 0.036 & $-0.121^{* * *}$ & 0.032 & 0.031 \\
\hline & $(0.040)$ & $(0.046)$ & $(0.035)$ & $(0.054)$ \\
\hline
\end{tabular}

Notes: This table reports ITT estimates of the Promise Academy and the Moving to Opportunity experiment evaluated by Kling, Liebman, and Katz (2007). Columns (1) and (3) are drawn from Table G2 of Kling, Liebman, and Katz (2007). For all MTO estimates we report the effects from the full experimental treatment that included the neighborhood quality restriction (as opposed to the Section 8-only treatment). Column (2) and (4) follow the specifications described in Table 4. Heteroskedasticity-robust standard errors are reported in parenthesis. The number of observations is reported below the standard error. ${ }^{* * *},{ }^{* *}$, and ${ }^{*}$ indicate statistical significance with $99 \%, 95 \%$, and $90 \%$ confidence, respectively. 
Appendix Table 6

Charter High School Lotteries

\begin{tabular}{lccccc}
\hline \hline & $\begin{array}{c}\text { Lottery } \\
\text { Grade }\end{array}$ & $\begin{array}{c}\text { Lottery } \\
\text { Years }\end{array}$ & $\begin{array}{c}\text { Lottery } \\
\text { Entrants }\end{array}$ & $\begin{array}{c}\text { Lottery } \\
\text { Winners }\end{array}$ & $\begin{array}{c}\text { Lottery } \\
\text { Losers }\end{array}$ \\
\cline { 2 - 6 } & $(1)$ & $(2)$ & $(3)$ & $(4)$ & $(5)$ \\
\cline { 2 - 6 } Denver Sci. and Tech. & 9 & $2006-2008$ & 952 & 439 & 513 \\
Match & 9 & $2000-2009$ & 4362 & 712 & 3650 \\
Noble Network & 9 & $2003-2005$ & 958 & 412 & 546 \\
Summit Preparatory & 9 & $2005-2007$ & 554 & 326 & 228 \\
\hline \hline
\end{tabular}

Notes: This table describes the charter school lotteries in our sample of high-quality charter schools used in Table 7. 
Appendix Table 7

Impacts of the Promise Academy on Possible Mechanisms

\begin{tabular}{|c|c|c|c|}
\hline & $\mathrm{CM}$ & ITT & LATE \\
\hline \multirow{4}{*}{$\begin{array}{l}\text { Panel A. Non-Cognitive Measures } \\
\quad \text { Self Esteem Index }\end{array}$} & $(1)$ & $(2)$ & $(3)$ \\
\hline & 0.000 & -0.138 & -0.224 \\
\hline & $(1.000)$ & $(0.110)$ & $(0.173)$ \\
\hline & 255 & 403 & 403 \\
\hline \multirow[t]{3}{*}{ Grit Index } & 0.000 & $-0.254^{* *}$ & $-0.402^{* *}$ \\
\hline & $(1.000)$ & $(0.113)$ & $(0.177)$ \\
\hline & 250 & 398 & 398 \\
\hline \multirow[t]{3}{*}{ Locus of Control } & 0.000 & 0.041 & 0.067 \\
\hline & $(1.000)$ & $(0.107)$ & $(0.166)$ \\
\hline & 254 & 398 & 398 \\
\hline \multicolumn{4}{|c|}{ Panel B. Discount Rates and Risk Aversion } \\
\hline \multirow[t]{3}{*}{ Discount Rate $(\sigma)$} & 0.000 & 0.045 & 0.073 \\
\hline & $(1.000)$ & $(0.110)$ & $(0.171)$ \\
\hline & 257 & 404 & 404 \\
\hline \multirow[t]{3}{*}{ Risk Aversion $(\sigma)$} & 0.000 & $0.248^{* *}$ & $0.400^{* *}$ \\
\hline & $(1.000)$ & $(0.103)$ & $(0.162)$ \\
\hline & 256 & 404 & 404 \\
\hline \multicolumn{4}{|l|}{ Panel C. Social Networks } \\
\hline \multirow[t]{3}{*}{ Academic Activities in Social Network } & -0.003 & 0.094 & 0.148 \\
\hline & $(0.754)$ & $(0.077)$ & $(0.118)$ \\
\hline & 252 & 398 & 398 \\
\hline \multirow[t]{3}{*}{ Risky Behaviors in Social Network } & 0.001 & -0.009 & -0.015 \\
\hline & $(0.574)$ & $(0.069)$ & $(0.105)$ \\
\hline & 252 & 398 & 398 \\
\hline \multicolumn{4}{|l|}{ Panel D. Sexual Behaviors } \\
\hline \multirow[t]{3}{*}{ Ever Had Sex } & 0.644 & -0.014 & -0.023 \\
\hline & $(0.480)$ & $(0.051)$ & $(0.080)$ \\
\hline & 253 & 398 & 398 \\
\hline \multirow[t]{3}{*}{ Condom Use } & 0.809 & -0.043 & -0.070 \\
\hline & $(0.395)$ & $(0.058)$ & $(0.089)$ \\
\hline & 162 & 255 & 255 \\
\hline \multirow[t]{3}{*}{ Other Contraceptive Use } & 0.466 & 0.068 & 0.110 \\
\hline & $(0.500)$ & $(0.066)$ & $(0.101)$ \\
\hline & 161 & 255 & 255 \\
\hline
\end{tabular}


Notes: This table reports estimates of the effect of attending the Promise Academy on mediating outcomes. Column (1) reports the mean and standard deviation of each variable for the control group. Column (2) reports ITT estimates of the impact of winning the admissions lottery. Column (3) reports LATE estimates of the impact of ever attending the Promise Academy using a winning lottery number as an instrument. All regressions control for the baseline demographic variables summarized in Table 2, a quadratic of 4th and 5th grade math and ELA test scores, lotteryyear indicators, indicators having a sibling enrolled in the same lottery, and a sibling-year interaction term. The sample includes lottery entrants in the survey sample. Results for condom and contraceptive use are restricted to students who report having ever had sex. Self Esteem is constructed from students' responses to ten self-evaluative questions from Rosenberg (1965). Grit is measured by the eight-question Short Grit Scale developed by Duckworth and Quinn (2009). Locus of Control is constructed from students' levels of agreement with four pairs of questions developed by Rotter (1966) and adapted for the NLSY. Academic Activities in Social Network is the average of standardized measures of the importance of studying to friends, the importance of education to friends, the importance of attending class to friends, and the importance of getting good grades to friends. Risky Behaviors in Social Network is the average of standardized inicators for a youth's friends using drugs, smoking cigarettes, having stolen an item worth less than $\$ 50$ dollars, having stolen an item worth more than $\$ 50$ dollars, getting in fights, carrying a handgun, or being in a gang. Condom Use is an indicator for using a condom during the last time the student had sexual intercourse. Other Contraceptive Use is an indicator for using a non-condom form of contraception. All variables are standardized to have mean zero and standard deviation one in the control group. See Web Appendix B for additional information on each variable. Heteroskedasticity-robust standard errors are reported in parenthesis. The number of observations is reported below the standard error. ${ }^{* * *},{ }^{* *}$, and ${ }^{*}$ indicate statistical significance with $99 \%, 95 \%$, and $90 \%$ confidence, respectively. 